\title{
Radiocarbon (AMS) dating the Classic Aurignacian, Proto-Aurignacian and Vasconian Mousterian at Gatzarria Cave (Pyrénées- Atlantiques, France)
}

Carolyn C. Barshay-Szmidt, Laura Eizenberg and Marianne Deschamps

\section{(2) OpenEdition}

\section{Journals}

Electronic version

URL: http://journals.openedition.org/paleo/2250

DOI: $10.4000 /$ paleo.2250

ISSN: 2101-0420

Publisher

SAMRA

\section{Printed version}

Date of publication: 15 December 2012

Number of pages: 11-38

ISSN: $1145-3370$

Electronic reference

Carolyn C. Barshay-Szmidt, Laura Eizenberg and Marianne Deschamps, « Radiocarbon (AMS) dating the Classic Aurignacian, Proto-Aurignacian and Vasconian Mousterian at Gatzarria Cave (PyrénéesAtlantiques, France) », PALEO [Online], 23 | 2012, Online since 18 March 2013, connection on 26 July 2020. URL : http://journals.openedition.org/paleo/2250 ; DOI : https://doi.org/10.4000/paleo.2250

This text was automatically generated on 26 July 2020 .

\section{c) (†) $\ominus$}

PALEO est mis à disposition selon les termes de la licence Creative Commons Attribution - Pas d'Utilisation Commerciale - Pas de Modification 4.0 International. 


\title{
Radiocarbon (AMS) dating the Classic Aurignacian, Proto- Aurignacian and Vasconian Mousterian at Gatzarria Cave (Pyrénées-Atlantiques, France)
}

\author{
Carolyn C. Barshay-Szmidt, Laura Eizenberg and Marianne Deschamps
}

\section{1- Introduction}

Gatzarria Cave is an important site for many reasons regarding the Middle to Upper Palaeolithic transition. Among them, it is one of the few sites to contain a Vasconian Mousterian industry, a facies often thought to represent a late stage in the Mousterian (Deschamps 2008) and thereby potentially associated with the late Neanderthals. It is also among the few sites to contain a stratified sequence of Proto-Aurignacian and Classic Aurignacian levels. Thus, it can help us to appreciate the chronological relationship between the Proto-Aurignacian and other Early Upper Palaeolithic or late Mousterian industries and contribute to evaluating the taxonomic link between them.

2 The principal objective of this article is to present the first ever radiocarbon dates done on the Vasconian Mousterian, Proto-Aurignacian and Classic Aurignacian layers of this site. We undertook dating of animal bones from three levels, sampling from the Musée National de Préhistoire (MNP) collections.

Dating is the focus, but this could only be achieved reliably at this site by integrally linking sampling for dating with a consideration of the larger contextual information of the site; this, in order to avoid obtaining incorrect dates. Thus, the historical, lithic, excavation methodology and stratigraphic aspects that are crucial for understanding what, why, where and how we sampled, are also presented. 
We begin by presenting the site and giving an overview of the assemblages relevant to this study and the excavation/recovery methods which were used by Laplace (section 2). We then present the work we have done to establish the chronology of this site. This includes details of the way in which we evaluated the excavation stratigraphic integrity and determined the most appropriate zone for sampling (section 3). After presenting the methodology of the dating used (section 4), we end the paper by placing our new AMS radiocarbon dating results (section 5) into the larger technological, chronological and human behavioural issues surrounding the late Mousterian and early Aurignacian periods (section 6). A detailed techno-economic re-evaluation of the industries of Gatzarria, a full re-evaluation of previous work and detailed comparisons with other industries, will constitute the subject of future articles focusing on those aspects.

\section{2 - Site characteristics}

\section{1 - History and methodology of excavation}

5 Gatzarria cave is located in the Basque area of France, in the Ossas-Suhare region, which is part of the Arbailles Massif (fig. 1). The cave, which faces north-east, is located within an Urgonian limestone cliff at the foot of Mount Hargagne. The main part of this small cavity is a $13 \mathrm{~m}$ long, $4 \mathrm{~m}$ wide, corridor and its maximum height was $2 \mathrm{~m}$ from the top of the deposits (fig. 2). The cave floor is sub-horizontal at the entrance, but rapidly angles downward towards the back of the cave (see implications for this below). It was discovered in 1945 by a group of spelunkers. A few test pits were dug by P. Boucher and G. Laplace until 1958, revealing Mousteroid and Aurignacian industries. More extensive excavations, amounting to a total of $37 \mathrm{~m} 2$ were then conducted between 1961 and 1976 by Laplace. The thickness of deposits excavated was variable, but never reached more than $2 \mathrm{~m}$. At no time (neither during test pitting, nor during excavation) was the bedrock reached.

6 The excavation and recording methods used at Gatzarria were those developed by Méroc and subsequently developed by him and Laplace (Laplace 1971 ; Laplace and Méroc 1954). This method involved the three-dimensional plotting of artifacts according to an orthogonal coordinate system. Excavation was done in horizontal bands ('décapages') following the sedimentary units. Pieces were labelled according to their three-dimensional coordinates. Some of them (especially the smaller fraction and/or unmodified lithic artifacts, as well as most of the fauna) were not labelled to precise depth, but only to archaeological layer and square, sometimes to sub-square and décapage. In the case of Gatzarria, a décapage corresponded to a $10 \mathrm{~cm}$-thick cut (known as 'Taille' $=\mathrm{T}$ in Laplace nomenclature) or $5 \mathrm{~cm}$-thick half-cut ( $\mathrm{T}$ sup ; $\mathrm{T}$ inf) and each square metre was sub-divided into 9 sub-squares. 
Figure 1 - Map of southern France and northern Spain showing location of Gatzarria Cave (\# 10) in the context of Aurignacian and Vasconian sites in the larger region. Caption : 1. Castillo, 2. Pendo, 3. Morin, 4. Murba, 5. Labeko Koba, 6. Amalda, 7. Abauntz, 8. Olha I and II, 9. Isturitz, 10. Gatzarria, 11. Harregi, 12. Brassempouy, 13. Les Abeilles, 14. Le Piage, 15. Bos del Ser, 16. Dufour, 17. Bize (Tournal), 18. Arbreda, 19. Reclau Viver, 20. I'Esquicho-Grapaou, 21. La Laouza, 22. Le Figuier, 23 Les Pêcheurs, 24. Mandrin, 25. Rainaude, 26. Grimaldi (Riparo Mochi). Black squares indicate Proto-Aurignacian or Classic Aurignacian sites, while white squares denote Vasconian sites ; some sites contain both, as shown by split black-white squares.

Figure 1 - Carte du sud de la France et du nord de l'Espagne indiquant la localisation de Gatzarria ( $\left.n^{\circ} 10\right)$ dans le contexte régional de sites aurignaciens et moustériens à hachereaux. Légende : 1. Castillo, 2. Pendo, 3. Morin, 4. Murba, 5. Labeko Koba, 6. Amalda, 7. Abauntz, 8. Olha I and II, 9. Isturitz, 10. Gatzarria, 11. Harregi, 12. Brassempouy, 13. Les Abeilles, 14. Le Piage, 15. Bos del Ser, 16. Dufour, 17. Bize (Tournal), 18. Arbreda, 19. Reclau Viver, 20. I'Esquicho-Grapaou, 21. La Laouza, 22. Le Figuier, 23. Les Pêcheurs, 24. Mandrin, 25. Rainaude, 26. Grimaldi (Riparo Mochi). Les carrés noirs désignent des sites du Protoaurignacien ou de l'Aurignacien ancien. Les carrés blancs représentent les sites du Moustérien à hachereaux. Certains sites comportent les deux industries (carré noir et blanc).

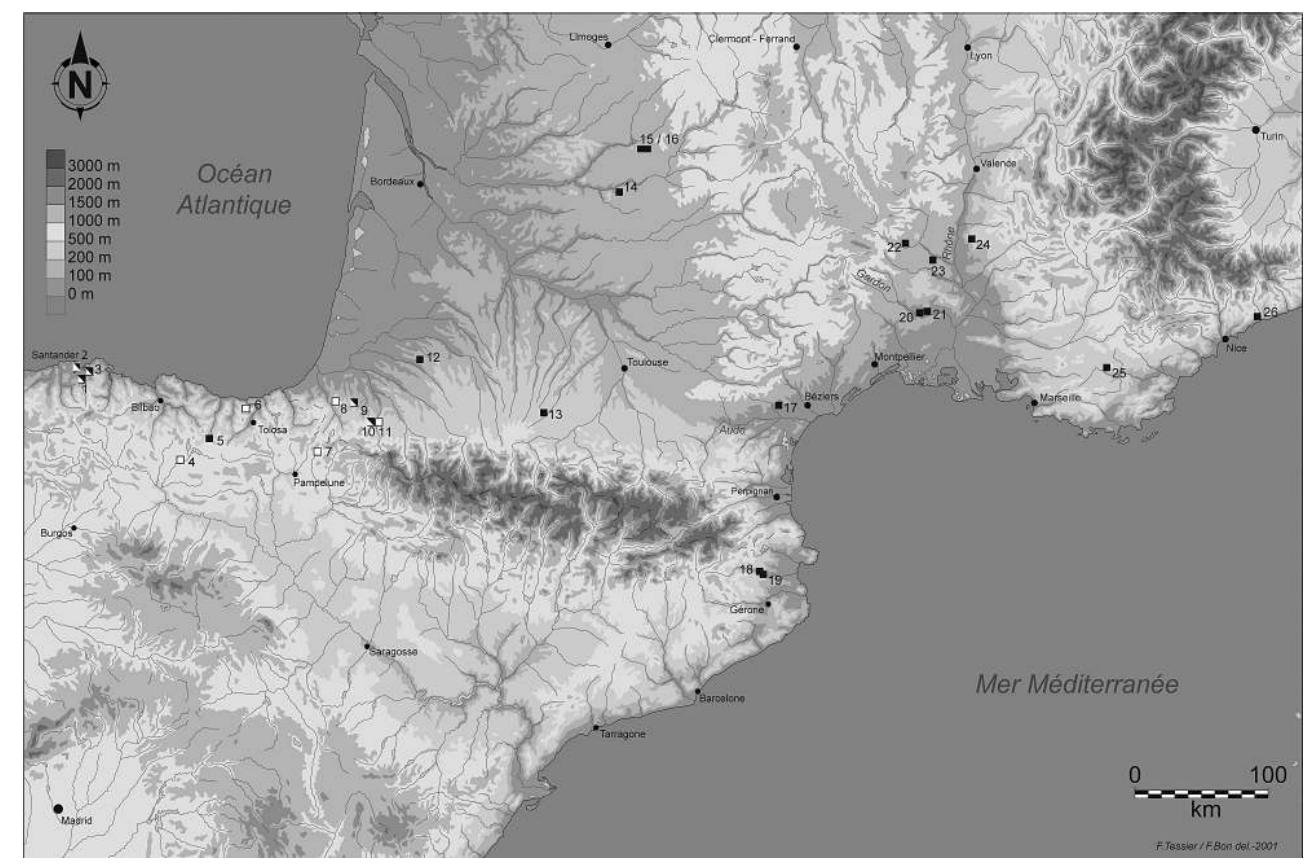


Figure 2 - Profile and excavation grid plan of Gatzarria Cave (after Lévêque and Miskovsky 1993). The entrance of the cave is on the left hand side in both drawings. The slope of the cave floor towards the back of the cave can be seen in the profile.

Figure 2 - Profil et plan de la grotte de Gatzarria (d'après Lévêque et Miskovsky 1993). L'entrée de la grotte se trouve à gauche dans les deux dessins. La pente vers le fond de la grotte se remarque dans le profil.

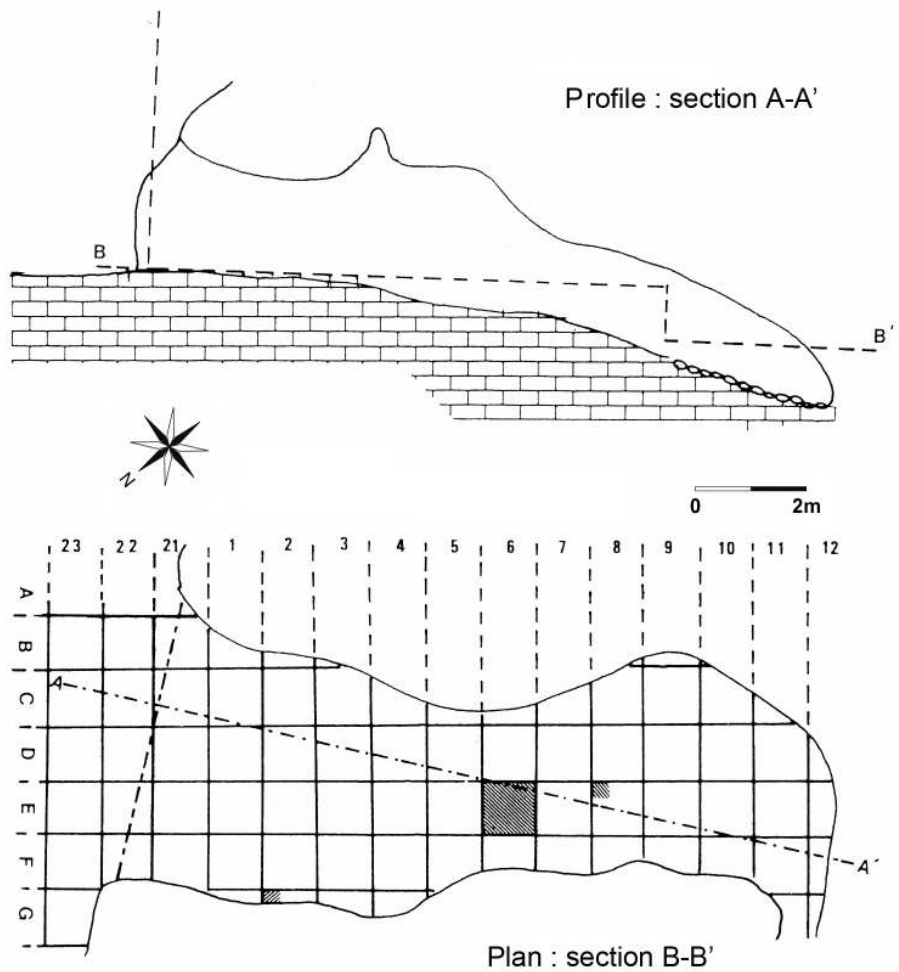

\section{2 - Stratigraphy of the deposits and description of archaeological assemblages}

7 As mentioned above, the thickness of the excavated deposits never exceeded $2 \mathrm{~m}$. The stratigraphy is shown in figure 3 and table 1 (see Saenz de Buruaga 1991 for more details).

The lithic and bone industries were studied by Laplace and Saenz de Buruaga ${ }^{1}$. For further information on these analyses and on the sedimentological aspects of the deposits, the reader is invited to consult the following references (Laplace 1966a, b ; Laplace and Saenz de Buruaga 2002 ; Laplace et al. eds. 2006 ; Lavaud 1980 ; Lévêque 1966 ; Saenz de Buruaga 1991 ; Simonet 2009 ; Tartar 2009). More recently, some of these assemblages have been examined as part of a Master's dissertation (Ready 2010) and doctoral theses, including by two of us, one on the Vasconian Mousterian lithic assemblage (MD) and the other on the Proto-Aurignacian lithic assemblages (LE). The aim of the Proto-Aurignacian Ph.D. research project is to elucidate in more detail the techno-typological characteristics and variability of the Proto-Aurignacian at this site (contained here in two different levels) and others. The Vasconian Mousterian research is aimed at characterizing techno-typology and raw material use in Vasconian Mousterian sites in the Basque-Cantabrian/Pyrenean zone in order to identify whether one overarching set of technical traditions can be demonstrated for the various Vasconian Mousterian assemblages, above and beyond the production of cleaver flakes. 
Alongside this, a study is also being done specifically aimed at this latter tool type to help unravel the part played by cultural and functional factors in its production in this particular context.

Figure 3 - Schematic stratigraphy of Gatzarria Cave. Numbers down the sides refer to the $10 \mathrm{~cm}$ thick cuts (décapages) (modified after Laplace 1971).

Figure 3 - Log stratigraphique de la grotte de Gatzarria par unités de fouilles. Les chiffres sur les bords représentent les décapages (modifié d'après Laplace 1971).

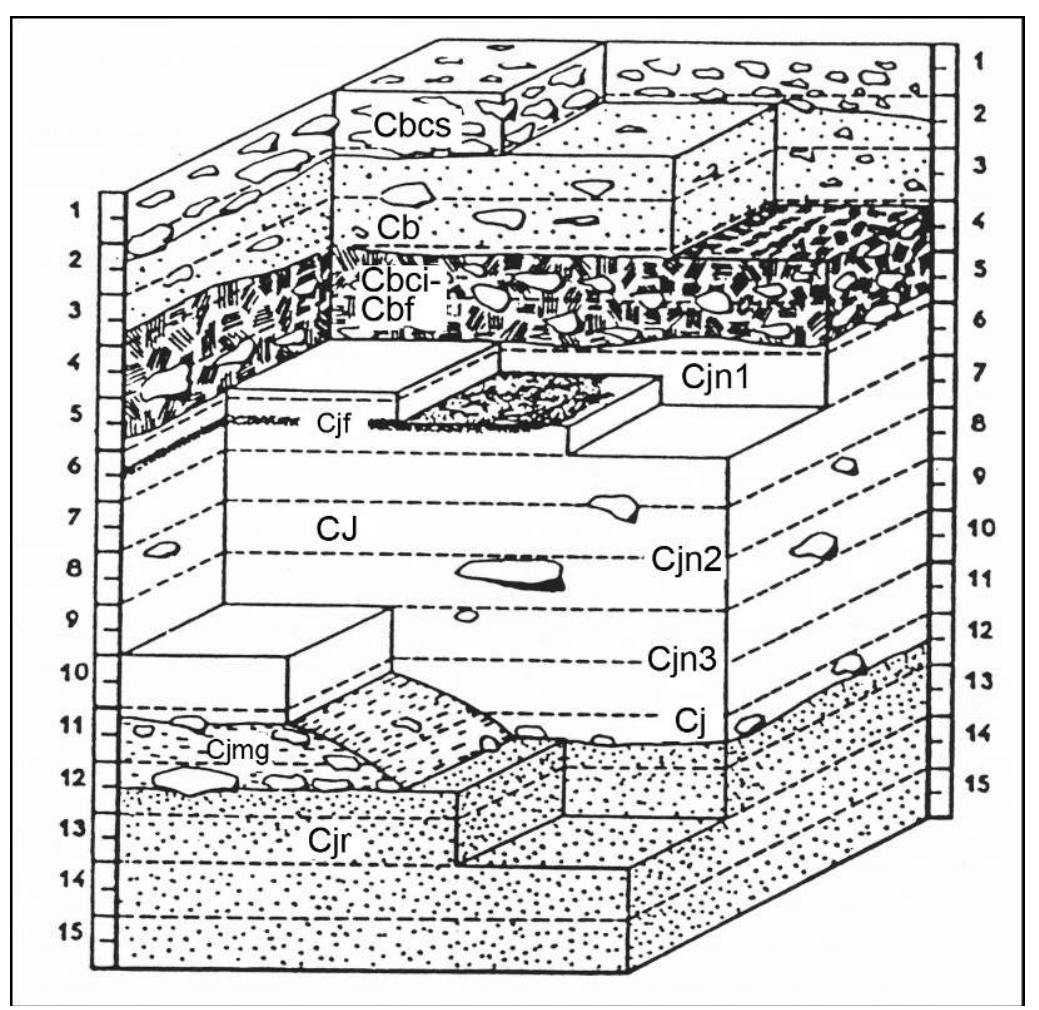

Table 1 - Stratigraphic sequence of Gatzarria Cave. Tableau 1 - Stratigraphie de la grotte de Gatzarria.

\begin{tabular}{|c|c|c|}
\hline Sedimentary Unit & $\begin{array}{c}\text { Archaeological } \\
\text { layer }\end{array}$ & Cultural Attribution given by G. Laplace (Original Laplace designation in French) \\
\hline $\mathrm{Cbn}-\mathrm{Cbr}$ & $\mathrm{Cbn}-\mathrm{Cbr}$ & Mixed layer (Couche remaniée) \\
\hline $\mathrm{Cbcs}$ & $\mathrm{Cbcs}$ & Some elements of Gravettian with Noailles burins (Rares éléments de Gravettien à Burins de Noailles) \\
\hline $\mathrm{Cb}$ & $\mathrm{Cb}$ & Late Aurignacian (Aurignacien récent) \\
\hline $\mathrm{Cbci}$ & $\mathrm{Cbci-Cbf}$ & Classic Aurignacian with split-based points (Aurignacien ancien à pointes à base fendue) \\
\hline $\mathrm{CJ}$ & $\mathrm{Cjn} 1$ & Protoaurignacian with carinated scrapers (Protoaurignacien à grattoirs carénés) \\
\hline $\mathrm{CJ}$ & $\mathrm{Cjn} 2$ & Protoaurignacian with bladelets (Protoaurignacien à lamelles à dos) \\
\hline $\mathrm{CJ}$ & $\mathrm{Cjn} 3$ & Châtelperronian (Châtelperronien) \\
\hline $\mathrm{CJ}$ & $\mathrm{Cj}$ & Mousterian (Moustérien) \\
\hline $\mathrm{Cjr}$ & Vasconian Mousterian (Moustérien à hachereaux) \\
\hline $\mathrm{Cjnr}(\mathrm{Cjrm} ; \mathrm{Cgr} ; \mathrm{Cgrm})$ & $\mathrm{Cr}$ & Mousterian/Tayacian (Moustérien / Tayacien) \\
\hline $\mathrm{Cr}(\mathrm{Crm} ; \mathrm{Cmo})$ & $\mathrm{Cr}$ &
\end{tabular}

9 In this article, we focus particularly on the three layers which we dated, Cjr (Vasconian Mousterian), Cjn2 (Proto-Aurignacian), and Cbf (Classic Aurignacian). The studied set from layer Cjr contains 1552 lithic pieces. Quartzite was the raw material most chosen (89\%), followed by flint (5\%) and lydite (3\%). All other raw materials were rarely used. The chaîne opératoire most commonly seen for the production of flakes is the unifacial Discoid method, followed by the bifacial method (fig. 4). The main goal was to make flakes whose entire periphery could be used as cutting edges. Naturally backed elements are relatively well represented due to the fact that the striking surfaces of quartzite cores are, for the most part, neocortical. We also find flakes whose back was formed by previous removals. It is interesting to note that there are very few pseudo- 
Levallois points. The assemblage contains six ophite cleavers (fig. 5). This raw material was used nearly exclusively to make this artifact-type. Retouched flake tools consist primarily of side-scrapers, followed by notches and denticulates (fig. 6); all other tool types are infrequent.

Figure 4 - Discoid cores from Gatzarria layer Cjr.

Figure 4 - Nucléus discoïdes de la couche Cjr de Gatzarria.

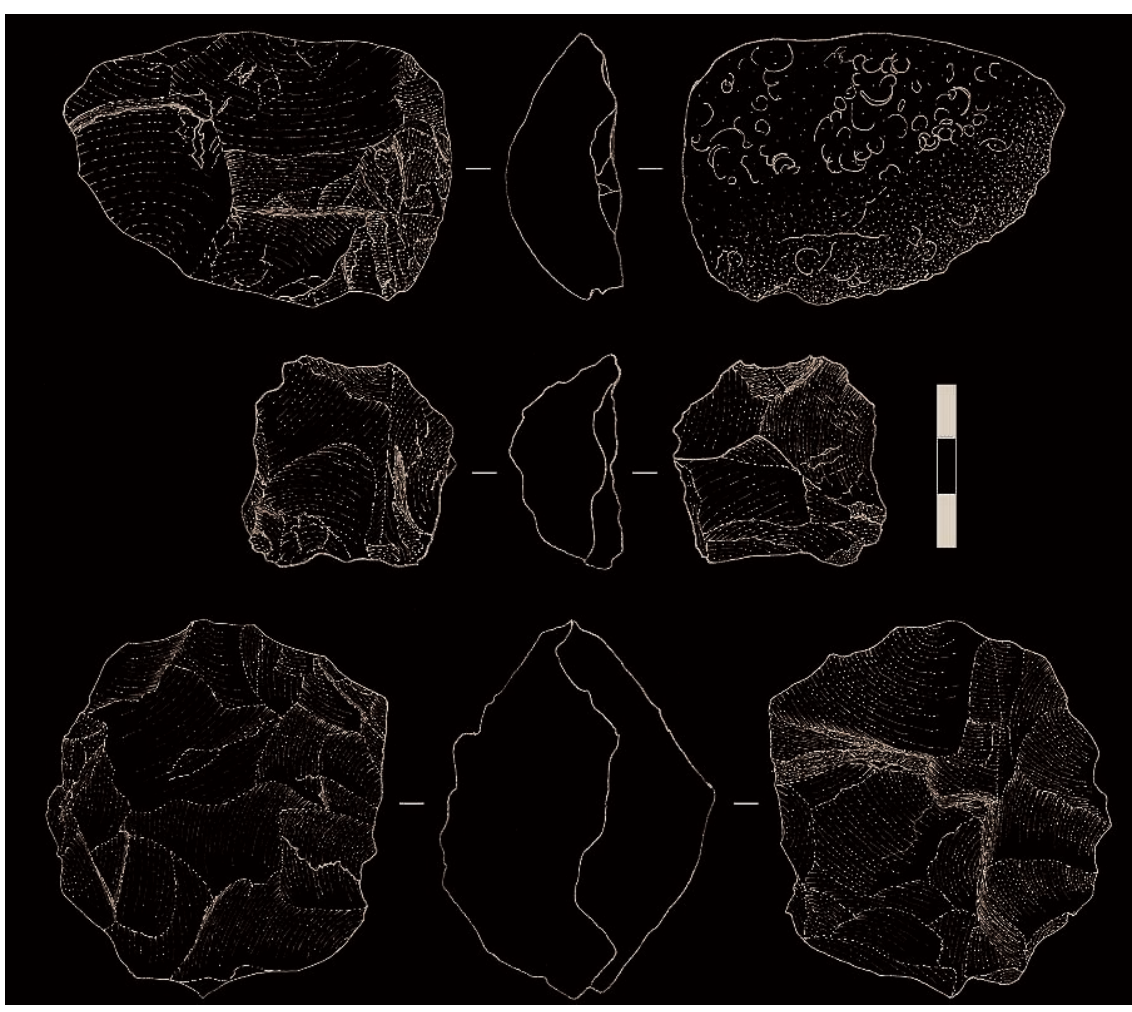

Figure 5 - Cleaver type 0 from Gatzarria layer Cjr (๔ MNP Les Eyzies-Dist.RMN-photo Ph. Jugie). Figure 5 - Hachereau de type 0 de la couche Cjr de Gatzarria (๑ MNP Les Eyzies-Dist.RMN-cliché Ph. Jugie).
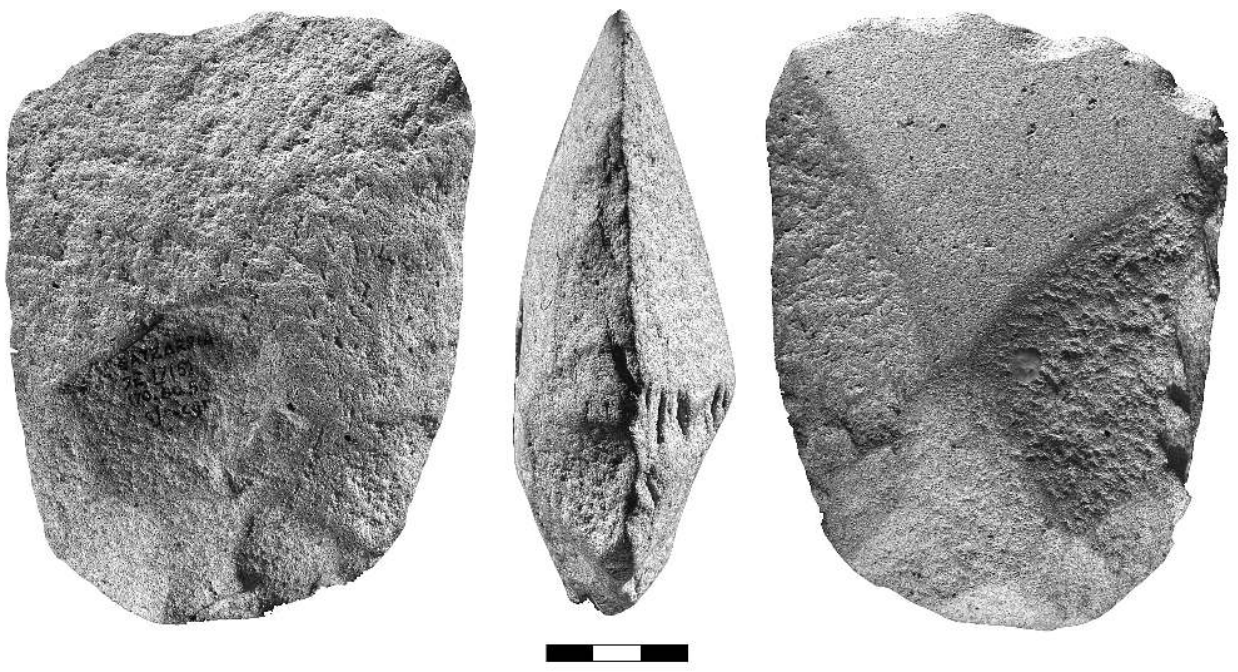
Table 2 - Overall lithic counts of layer Cjn2, all raw materials combined.

Tableau 2 - Décompte général des pièces lithiques de la couche Cjn2, toutes matières premières confondues.

\begin{tabular}{|l|c|c|}
\hline Type of piece & Number & Percentage \\
\hline Flakes $>1 \mathrm{~cm}$ & 550 & \\
\hline Flakes/debris $<1 \mathrm{~cm}$ & 378 & $53.40 \%$ \\
\hline Total flakes & 928 & $30.20 \%$ \\
\hline $\begin{array}{l}\text { Blades, bladelets, } \\
\text { blade/bladelet-like flakes }\end{array}$ & 524 & \\
\hline $\begin{array}{l}\text {-of which initialization, crested } \\
\text { and neo-crested blades and } \\
\text { bladelets }\end{array}$ & 21 & \\
\hline Other technical products & 32 & $1.80 \%$ \\
\hline Core tablet & 4 & $0.20 \%$ \\
\hline Partial core tablet & 65 & $3.70 \%$ \\
\hline Blade/bladelet core & 35 & $2 \%$ \\
\hline Untested or tested block & 36 & $2 \%$ \\
\hline Retouched piece & 113 & $6.50 \%$ \\
\hline -of which nucleiform & 11 & $100 \%$ \\
\hline Grand total & 1737 & \\
\hline
\end{tabular}

Analyses are still underway regarding the Proto-Aurignacian layers, but preliminary results can already be presented. Archaeological layer Cjn2 (tabl. 2 and 3) fits completely within the definition and characterization of the Proto-Aurignacian. It is the richer of two superposed Proto-Aurignacian layers, containing 1737 flint pieces in the sampled set (see below for what is meant by 'sampled set'). This industry is geared towards the exclusive production of small blades, as well as elongated, slender, rectilinear-profile bladelets produced as part of the same operational sequence. Bladebladelet blanks thus dominate among the tools, representing $72.5 \%$ of the transformed blanks (74 of 102, not including core tools such as carinated end-scrapers and burins). The rest of the tools were made on non-standardized blanks obtained from the shaping and maintenance phases of blade-bladelet production. Among the retouched blades and bladelets, Dufour bladelets (sub-type Dufour) are the most prevalent (37 out of 74 retouched blades/bladelets) (fig. 7 and 8 ). These are also the most standardized elements in the assemblage in terms of size and morphology, with thickness ranging from 1-2.5 mm and width from 3.5-9 mm. Most of them are broken, with the longest being $32.5 \mathrm{~mm}$. As is typical for this artifact type, the bladelets are retouched on one edge of the ventral surface (inverse retouch), with some of them also being dorsally retouched on the opposite edge (alternate retouch). In this assemblage, the inverse retouch was nearly exclusively done on the right edge (34 of 37 cases), as is usually the case for this artifact type (Demars et Laurent 1989 - p. 102 ; Rigaud 1982 - p. 366). It is marginal (often very marginal) and semi-abrupt, thus barely transforming the blank. Blanks were made using local raw materials or generally those from the neighbouring environment ; flysch dominates, with $93.8 \%$ of the pieces of identified raw material type belonging to this group (we could not identify the raw material of $20 \%$ percent of the assemblage). 
11 Although the assemblages from archaeological layers Cjn2 and Cjn1 both display ProtoAurignacian characteristics, the Cjn1 assemblage is, in certain respects, more aligned with the Classic Aurignacian. It is for this reason that Laplace had described and viewed it as a Proto-Aurignacian transitioning towards the Classic Aurignacian. This is seen in the tool types represented. There are only 5 Dufour bladelets out of 50 tools on blades/ bladelets and out of 92 tools in total (tabl. 4 and 5). Splintered pieces and carinated endscrapers are well represented (28\% of the tools compared with $2.6 \%$ in Cjn2) and retouch is much more frequently scaled and invasive, thus resembling Aurignacian retouch which is very rare or absent in Proto-Aurignacian assemblages. The raw material aspects are also noteworthy. An initial examination of the Classic Aurignacian assemblage of archaeological layer Cbf revealed that the types of flints used were overall the same as those used in Proto-Aurignacian assemblage Cjn2, but in reverse proportion. As such, Iholdy flysch flint, which accounts for $60 \%$ of the raw material in Cjn2, is only marginally represented in Cbf. This rarity is also the case in Cjn1, where Iholdy flint represents only $8.5 \%$ of the assemblage. It should be noted, though, that the assemblage from Cjn1 is smaller than Cjn2 and Cbci-Cbf $(\mathrm{N}=1100)$ and that this 'thin and sporadic layer, located in the upper part of the unit, is only occasionally seen as a thin line of hearths or, in other instances, as a horizon of minute traces of soot' (Laplace 1966 b - p. 125, our translation). Furthermore, it is frequently mentioned in the excavation notebooks (kept in the MNP archives) that it is very difficult or impossible to see the contact surface between Cbf and Cjn1 visually in the stratigraphy. Also, Cjn1 and Cjn2 are found in the same sedimentary unit (see below and Table 1) and are in contact with each other. Consequently, at this stage of our own analysis, we cannot exclude the hypothesis that the Cjn1 assemblage could be, at least in part, a mix of Proto-Aurignacian assemblage Cjn2 and Classic Aurignacian assemblage Cbf. For these reasons, as a precaution, we chose not to date Cjn1.

The Classic Aurignacian assemblages of archaeological layers Cbci-cbf have not been reanalysed recently. Published findings (Laplace 1966a,b; Saenz de Buruaga 1991), however, clearly show them to be attributable to the Classic Aurignacian. Readers are also invited to consult the recent synthesis of typological information carried out by Normand (2005) based on these publications and their drawings. 
Figure 6 - Retouched tools from layer Cjr at Gatzarria. 1: Side-scraper with basal thinning, made from Flysch flint ; 2 : Double side-scraper in Chalosse flint ; 3 - 5 : Quartzite side-scrapers ; 6, 7 : Quartzite denticulates.

Figure 6 - Outillage retouché de la couche Cjr de Gatzarria. 1 : racloir à base amincie en silex du flysch ; 2 : racloir double en silex de Chalosse ; 3 - 5 : racloirs en quartzite ; 6, 7 : denticulés en quartzite.

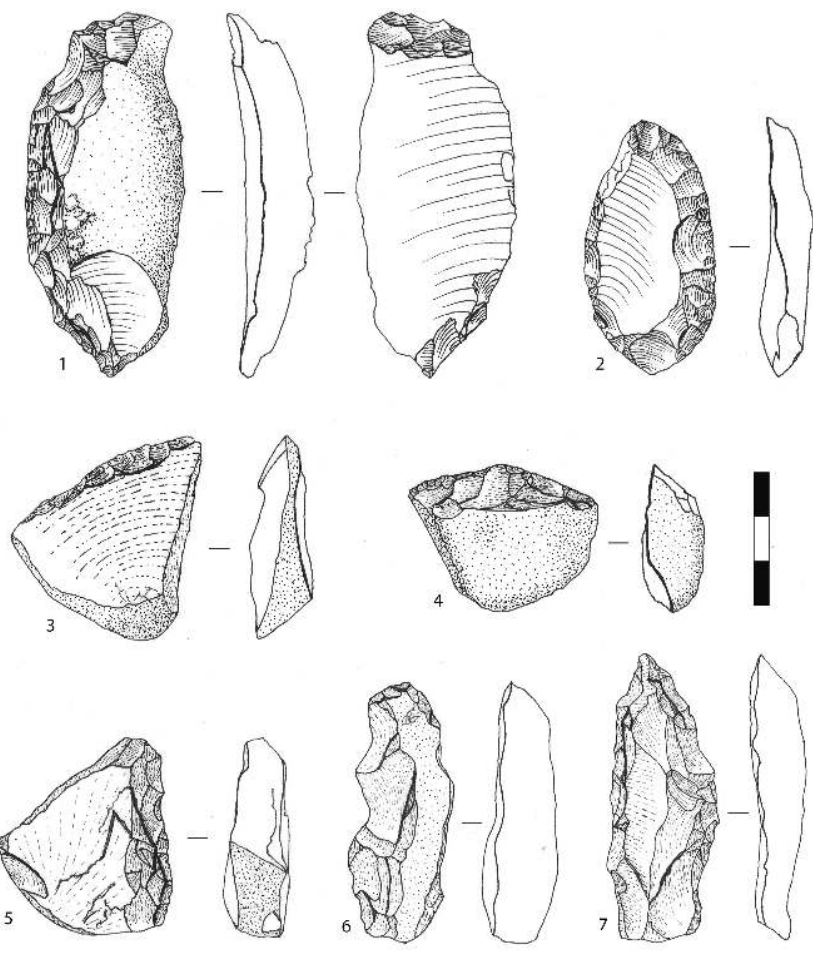

Table 3 - Retouched pieces from layer Cjn2, divided by blank type, all raw materials combined. Tableau 3 - Outillage de la Cjn2 par types de supports, toutes matières premières confondues.

\begin{tabular}{|l|c|c|c|}
\hline Type & Blades/bladelets & $\begin{array}{c}\text { Other blank } \\
\text { types }\end{array}$ & $\begin{array}{c}\text { Total by tool } \\
\text { type }\end{array}$ \\
\hline End scraper on blade & 1 & & $\mathbf{1}$ \\
\hline End scraper on retouched blade & 1 & & $\mathbf{1}$ \\
\hline Circular end scraper & & 2 & $\mathbf{2}$ \\
\hline Atypical carinated end scraper & & 2 & $\mathbf{2}$ \\
\hline Total End scrapers & $\mathbf{2}$ & $\mathbf{4}$ & $\mathbf{6}$ \\
\hline Angle burin on break & 1 & & $\mathbf{1}$ \\
\hline Burin on straight retouched truncation & 1 & 1 & $\mathbf{2}$ \\
\hline Nucleiform burin & & 9 & $\mathbf{9}$ \\
\hline Indeterminate burin & 1 & & $\mathbf{1}$ \\
\hline Total Burins & $\mathbf{3}$ & $\mathbf{1 0}$ & $\mathbf{1 3}$ \\
\hline Truncated blade/bladelet & 1 & & $\mathbf{1}$ \\
\hline Blade/bladelet with direct retouch & 31 & & $\mathbf{3 1}$ \\
\hline $\begin{array}{l}\text { Bladelet with inverse or alternate } \\
\text { retouch ("Dufour", sub-type Dufour) }\end{array}$ & 37 & & $\mathbf{3 7}$ \\
\hline Total retouched blades/bladelets & $\mathbf{6 9}$ & & $\mathbf{6 9}$ \\
\hline Splintered piece & & 1 & $\mathbf{1}$ \\
\hline Side scraper & & 3 & $\mathbf{3}$ \\
\hline Retouched flake & & 11 & $\mathbf{1 1}$ \\
\hline Fragment of retouched piece & & 2 & $\mathbf{8}$ \\
\hline Indeterminate & $\mathbf{3 2}$ & $\mathbf{2}$ \\
\hline Total by blank type & & \\
\hline
\end{tabular}


Figure 7 - Dufour bladelets (sub-type Dufour) from layer Cjn2. Note the high degree of fragmentation. The inverse retouch is often located on the medial portion of the blank. Figure 7 - Gatzarria Cjn2, lamelles Dufour sous-type dufour. Notez la forte fragmentation des pièces et la retouche inverse jamais appointante, souvent localisée sur la partie mésiale du support.

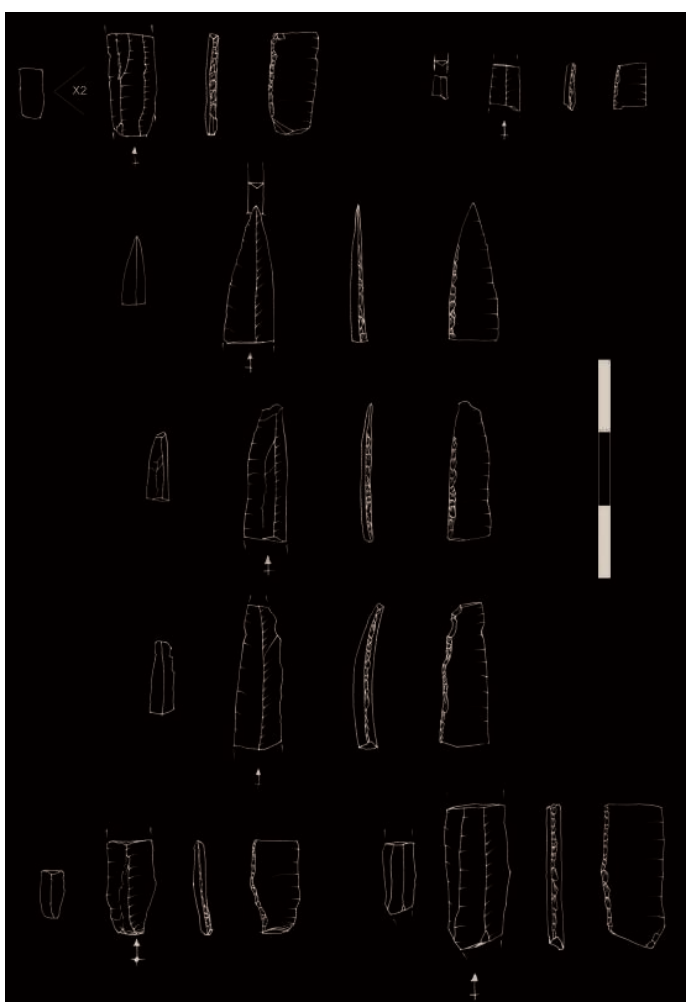


Figure 8 - Bladelets from Gatzarria layer Cjn2, retouched on their dorsal surface, along one or both edges.

Figure 8 - Gatzarria Cjn2, lamelles à retouche directe sur 1 ou 2 bords.

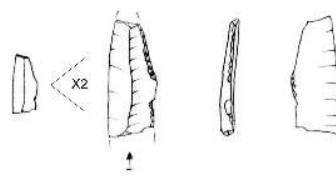<smiles>CC=CC=CC</smiles>

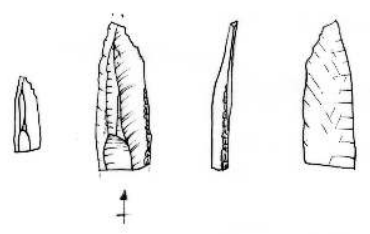

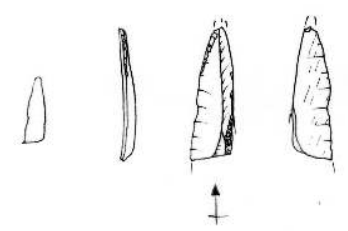

\section{3 - Using the Laplace stratigraphy and nomenclature for new analyses}

In light of the risk of post-depositional disturbance, modern methods of study place much emphasis on ensuring the validity of archaeological layers. The likelihood of layers mixing is fairly high in karstic contexts and the extent of this can be difficult to estimate in excavations carried out a long time ago.

This clearly poses a risk of error for any analysis of the material, although such an error might be noticeable in some cases if obviously out-of-place artifacts were present. It poses a serious and very likely risk of grave error, however, in the case of radiocarbon dating of the material in the collection because such stratigraphic problems would go unnoticed without refitting or similar post excavation analyses. Stratigraphically incoherent dates might be a sign of a stratigraphic problem, but a) this is late to discover that one has unnecessarily spent financial resources and $b$ ) dates can be incoherent for other reasons, such as contamination problems, having nothing to do with the stratigraphy.

Below, we describe the analyses we did to assess the stratigraphy and to identify the most problematic zones at Gatzarria. Such work helped us identify the zones least affected by taphonomic excavation problems and thus the ones best suited for radiocarbon sampling. We then go on to describe the samples chosen for dating, the laboratory methodology used on them and the results. 


\section{1 - Assessment of Gatzarria Laplace excavation stratigraphic integrity}

Examining the stratigraphic profile of the infilling (fig. 2) can lead one to suspect that the deposits followed the topography of the site, and thus that they would be subhorizontal at the front, dipping progressively towards the back of the cave. As a result, one would expect the layers at the back to be far more mixed. Our observations on the assemblages from Cjn2 and Cjr confirmed this hypothesis. Our analyses revealed that the material from the posterior portion of the cave was far less homogeneous than that of the anterior zone. We found this to be the case not only in terms of types of artifacts, but also in the representativeness of raw materials and in the surface condition of the pieces. For instance, we found a type of flint in the back portion of Cjn2 which is not present in the sub-horizontal front area of that layer but is, however, found higher up in the stratigraphy. These observations led us to consider only the material from the anterior zones of the cave for techno-typological analyses as well as for radiocarbon sampling. We refer to this material as the 'sampled set'.

Table 4 - Overall lithic counts of layer Cjn1, all raw materials combined. Tableau 4 - Décompte général du matériel de la Cjn1, toutes matières premières confondues.

\begin{tabular}{|l|c|c|}
\hline Type of piece & Number & Percentage \\
\hline Flakes $>1 \mathrm{~cm}$ & 272 & \\
\hline Flakes $<1 \mathrm{~cm}$ & 355 & \\
\hline Total flakes & $\mathbf{6 2 7}$ & $\mathbf{5 7 \%}$ \\
\hline Blade, blade-like flake & 42 & $3.80 \%$ \\
\hline -of which crested blade, neo-crest & 2 & \\
\hline Bladelets/bladelet-like flake & 310 & $28.20 \%$ \\
\hline Total blades/bladelets & $\mathbf{3 5 4}$ & $\mathbf{3 2 . 2 0} \%$ \\
\hline Core tablet (of which partial core tablet) & $13(12)$ & $1.20 \%$ \\
\hline Other technical product & 6 & $0.50 \%$ \\
\hline Bladelet core & 19 & $1.70 \%$ \\
\hline Untested or tested block & 5 & $0.50 \%$ \\
\hline Retouched piece (of which nucleiform) & $92(16)$ & $8.40 \%$ \\
\hline Grand total & $\mathbf{1 1 0 0}$ & $100 \%$ \\
\hline
\end{tabular}


Table 5 - Retouched pieces from layer Cjn1, divided by blank type, all raw materials combined. Tableau 5 - Outillage de la Cjn1 par types de supports, toutes matières premières confondues.

\begin{tabular}{|c|c|c|c|c|c|}
\hline Type & Blades & Bladelets & $\begin{array}{c}\text { Other blank } \\
\text { types }\end{array}$ & $\begin{array}{c}\text { Indeterminate } \\
\text { (blade or flake) }\end{array}$ & $\begin{array}{c}\text { Total by too } \\
\text { type }\end{array}$ \\
\hline End scraper on blade & 5 & & & & 5 \\
\hline End scraper on retouched blade & 9 & & & & 9 \\
\hline Double end scraper & 2 & & 1 & & 3 \\
\hline Carinated end scraper & & & & 10 & 10 \\
\hline Atypical carinated end scraper & & & & 1 & 1 \\
\hline Total End scrapers & & & & & 28 \\
\hline Dihedral burin & & & 1 & & 1 \\
\hline Burin on straight retouched truncation & 1 & & 1 & & 2 \\
\hline carinated burin & & & 1 & & 1 \\
\hline Total Burins & & & & & 4 \\
\hline Truncated blade/bladelet & & 1 & & & 1 \\
\hline Blade/bladelet with direct retouch on 1 or 2 edges & 11 & 10 & & & 21 \\
\hline Bladelet with inverse or alternate retouch ("Dufour") & & 5 & & & 5 \\
\hline Total retouched blades/bladelets & & & & & 27 \\
\hline Splintered piece & 2 & & 6 & 6 & 14 \\
\hline Side-scraper & & & 2 & & 2 \\
\hline Retouched flake & & & 5 & & 5 \\
\hline Fragment of retouched piece & 2 & & 3 & 2 & 7 \\
\hline Indeterminate & 2 & & 3 & & 5 \\
\hline Total by blank type & 34 & 16 & 31 & 19 & 92 \\
\hline
\end{tabular}

In his 1962 site report, Laplace stated that "There was no sterile horizon between the various archaeological layers [of sedimentary unit CJ], although all are clearly individualized, with no indication or likely possibility of contamination between them" (Laplace 1962). Although he took care to identify sedimentary changes during excavation, as mentioned above he excavated in horizontal décapages. In addition, the four layers of $\mathrm{CJ}$ - the uppermost Mousterian layer $(\mathrm{Cj})$, the Chatelperronian layer (Cjn3) and the two Proto-Aurignacian layers (Cjn2 and Cjn1) -- are all contained in the same sedimentary unit and were superposed without any sterile layers separating them (Laplace 1966b). As a result, "[CJ was divided] into horizons/archaeological levels using only Cartesian coordinates" (Laplace 1963). Given the sloping topography and the horizontal way in which the site was excavated, it is therefore to be expected that mixing will have occurred between these layers, at least in part.

Thus, we used the method of vertically projecting artifacts to "correct or confirm, within the sequence of strata, the boundaries of cultural levels as established during the excavation" (Villa 1982 - p. 277). We found that the layers were indeed in contact with each other and that they overlapped partly. The analyses we conducted on Cjn2 and Cjr indicate that in the sub-horizontal zones of the cave, these layers are internally coherent in terms of techno-typology. As well, the surface condition is identical across artifacts, bolstering the argument of overall homogeneity of the anterior zone parts of these levels. According to us, the techno-typo-taphonomic homogeneity of the sampled assemblages is a strong argument in favour of their stratigraphic integrity, thus making sampling for dating feasible within this zone.

In her faunal analysis of Mousterian archaeological layer Cj, Ready (2010) came to a similar conclusion regarding overlapping and mixing of layers, as well as problems in the layer attribution of artifacts, finding that this was especially problematic in certain parts of the cave. Although this was not a layer studied by us, her findings bolster our argument that care must be taken in choosing which artifacts to include in any analysis from Gatzarria, be it for subsistence-related analyses, as in her case, or for choosing samples for dating, as in ours.

The stratigraphy at Gatzarria also includes a layer which was attributed to the Châtelperronian by Laplace (Cjn3). We did not have the chance to re-evaluate this assemblage given that others were currently working on it. As such, we did not take samples from it. Based on our existing research at the site, however, a number of 
factors lead us to suspect that this layer may be mixed with material from layers above and below it. For one thing, layer Cjn3 is very thin. As described above, our analyses have shown that post-depositional processes were acting on this site, so a thin layer is problematic. In addition, Cjn3 is part of the same sedimentary unit as layers above and below it and is thus indistinguishable from these. This hypothesis of mixing needs to be tested more extensively on the assemblage itself, but existing information already made this layer questionable and problematic for dating.

\section{2 - Selecting the sampling zone}

The zone from which to sample was thus chosen in light of the various issues outlined above. The projection of pieces also shows that the slumping towards the back of the cave is strong from row 5, but is already happening to some extent in row 4 (see fig. 2). Thus, sampling from rows 4 and above was not considered reliable by us. The material from the front of the excavation (rows 22 and 21) were less precisely extracted and labelled ; row 1, also near the front of the cave, is poor in material. As a result, sampling was avoided from these front rows. This left us with rows 2 and 3. Given that the latter has more material and has a more dilated stratigraphy (easier to avoid contact surface with other layers) our preference was for row 3. In the North-South direction, rows E and $\mathrm{F}$ are the richest in material. Taking all this into account, samples were examined for selection from preferred squares $3 \mathrm{E}$ and $3 \mathrm{~F}$, but also $2 \mathrm{E}$ and $2 \mathrm{~F}$.

It is also worth noting that the study of the Proto-Aurignacian layers included some non systematic refitting and conjoining work (by LE). The number of pieces is very small $(\mathrm{N}=23)$ and thus not sufficient on its own, but combined with other evidence described, it confirms our conclusions. Work of this type, done for the purpose of stratigraphic assessment, has been shown to be particularly useful in karstic contexts. It consists of making projections of such artifacts within and between layers to assess the degree of dispersion within the deposits and thus test the integrity and amount of post-depositional disturbance of the stratigraphy (Bordes 2002; Cahen and Moeyersons 1977 ; Cziesla et al. 1990 ; Hofman 1986 ; Tixier 1978 ; Villa 1982 ; Villa and Courtin 1983). The results of the initial refitting and conjoining test carried out at Gatzarria (fig. 9) demonstrate no significant vertical displacements in the zone under consideration. The only inter-level refit found (refit \# 5 in Figure 9), which unites two pieces marked as coming from Cjn1 and Cjn2, is consistent with this finding. The stratigraphically higher one was found at the contact zone between the two layers and could therefore have been part of Cjn2; the one found lower was aligned with the North-South slope of the cave. In future we hope to expand this study. For now, this test bolsters the technotypological findings of the lithics from this zone, demonstrating minimal risk of contamination between layers in the sampled zone.

\section{4 - Dating methodology}

\section{1 - Sampling}

Our radiocarbon dating at Gatzarria relates to a larger Wenner-Gren Foundationfunded chronometric project, directed by one of us (CCBS), to gain a more precise and accurate handle on the late Mousterian and early Upper Palaeolithic chronology, 
particularly in the larger southern France region (Mediterranean, Pyrenean and Southwestern regions) (Szmidt 2009 ; Szmidt et al. 2010a,b,c). The dating sampling protocol of this larger chronometric project has been described already (Szmidt et al. 2010c). Readers are invited to consult these for details. We have applied this protocol as much as possible here, while operating within the well-known constraints imposed by selecting from a previously excavated site, whose labelling and recording protocol and standards differ from the ideals of today. The fairly detailed 3D positioning and labelling used by Laplace made this far more feasible than would be possible for other sites. The willingness and openness of the curators of the museum to grant us access to all the material for the purposes of looking for potential samples, also helped enormously. Curatorial issues, including preservation, often make it difficult for museums to allow extensive access and/or sampling of artifacts. 
Figure 9 - Projection plot showing refits along a North-South cut of bands 1-4 at Gatzarria Cave. The upper and lower dotted lines in all the graphs represent the lower stratigraphic limits of Cjn 1 and Cjn2, respectively (estimated based on the 3D plotted pieces). The numbers along the left edge in the three graphs represent depth in $\mathrm{cm}$, corresponding to the levels defined by Laplace during excavation. The numbers along the top represent band numbers along the North-South axis (see fig. 2 for excavation grid). Only fully provenienced pieces $(x, y, z)$ were used for the projection, i.e. 14 pieces out of a total of 23 refitted or conjoined in 8 groups. There are therefore 5 refits projected. Top graph shows refit \# 1 (consisting of 4 pieces, indicated by triangles) and refit \# 2 (3 pieces, indicated by lozenges). Middle graph shows refit \# 3 (3 pieces, indicated by triangles) and refit \# 4 ( 2 pieces, indicated by lozenges). Lower graph shows refit \# 5 ( 2 pieces, indicated by circles). In terms of their spatial distribution in an East-West direction, the refits fit within three bands (E to $G$ ). Refits 2 and 5 are contained within band $F$; refit 4 within bands $E$ and $F(E-W$ distance $=50 \mathrm{~cm})$; refit 1 within bands $F$ and $G$ (maximum $E-W$ distance is $1 \mathrm{~m}$ ); refit 3 within bands $E$ to $G$ (covering a maximum distance of $1.20 \mathrm{~m}$ ). The two dated samples of Cjn2 are represented by squares in all three graphs.

Figure 9 - Projection des remontages sur une coupe Nord-Sud des bandes 1 à 4 de Gatzarria. Les lignes en pointillés correspondent aux limites inférieures de Cjn1 et Cjn2 (estimation à partir des pièces côtées). L'échelle de profondeur (à gauche dans les graphes) est en centimètres, et correspond aux niveaux définis à la fouille. Les chiffres 1 à 4 (au sommet de chaque graphe) correspondent aux bandes horizontales du plan de fouille (voir fig. 2). La projection ne concerne que les pièces précisément côtées $(x, y, z), c^{\prime}$ est-à-dire 14 pièces pour un total de 23 remontées ou raccordées en 8 lots. Il y a donc 5 remontages projetés. Le graphe supérieur montre le remontage \# 1 (4 pièces, indiquées par des triangles) et le remontage \# 2 (3 pièces, indiquées par des losanges). Le graphe central montre le remontage \# 3 (3 pièces, indiquées par des triangles) et le remontage \# 4 (2 pièces, indiquées par des losanges). Le graphe inférieur montre le remontage \# 5 (2 pièces, indiquées par des cercles). Concernant leur répartition horizontale dans l'axe est-ouest, les remontages se répartissent au total sur 3 bandes ( $E$ à $G$ ). Les remontages 2 et 5 se limitent à la bande $F$. Le remontage 4 aux bandes $E$ et $F$ (distance $E-O$ : $50 \mathrm{~cm}$ ); le remontage 1 aux bandes $F$ et $G$ (distance $E-O$ : maximum $1 \mathrm{~m}$ ). Le remontage 3 aux bandes $E$ à $G$ (sur une distance maximum d'1,20m). La localisation des deux échantillons datés de Cjn2 est représentée par les symboles carrés dans les trois graphes.
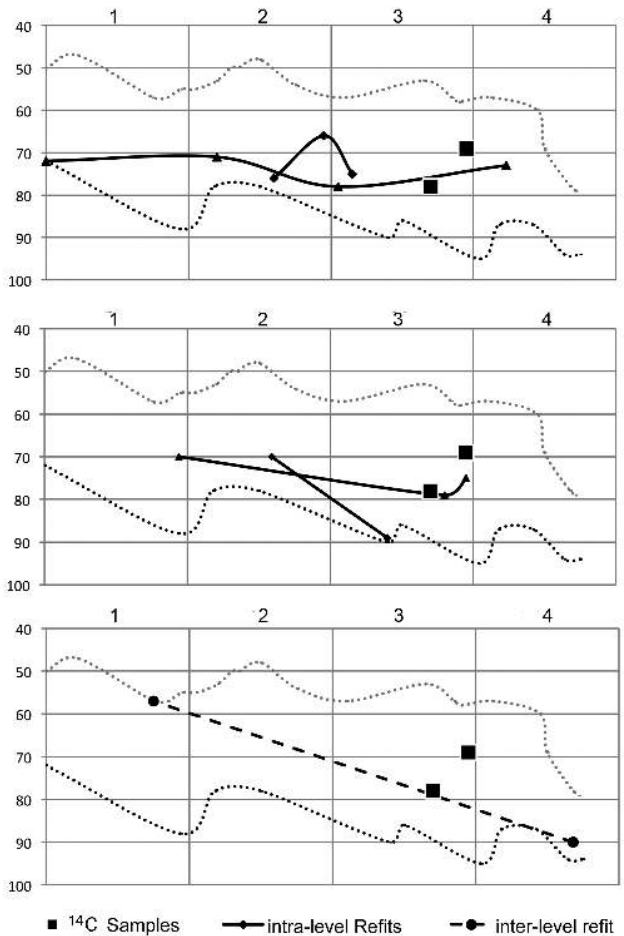

24 As per the sampling protocol of this overall regional dating project, for Gatzarria we wanted samples which were as precisely provenienced as possible (preferably $\mathrm{z}, \mathrm{x}, \mathrm{y}$ coordinates, but at least $\mathrm{x}, \mathrm{y}$ and décapage) ; that could be identified taxonomically (preferably to species, but at least enough to rule out bones of carnivores) ; preferably 
thick long bones in good condition ; and preferably bones with direct evidence of human involvement (cutmarks or impact scars).

Two samples from each of the three layers (Cbf, Cjn2, Cjr) were chosen (see tabl. 6 for provenience and taxonomic details). Layer Cjn2 is located between $60 \mathrm{~cm}$ and $90 \mathrm{~cm}$ depth in row 3. In order to minimize the potential problem of mixing between it and adjoining layers Cjn3 (below) and Cjn1 (above) at their contact surfaces, we sampled from the middle of the layer. Thus, when choosing samples for dating from Cjn2, we only considered bones bearing precise depth coordinates to make this feasible (as opposed to only décapage information). As shown in Table 6, the two dated samples were found at $69 \mathrm{~cm}$ and $78 \mathrm{~cm}$ depths (shown as squares in all the graphs of Figure 9).

Regarding the Vasconian Mousterian layer ( $\mathrm{Cjr}$ ), the analysis by Deschamps (2008) found that the back of the cave was stratigraphically mixed, as was the case for the Aurignacian levels. As a result, we sampled for dating from the middle section, in particular the square which had been most studied in this recent technological evaluation (square 3F). This square showed a concentration of cleavers, the typologically diagnostic artifact of this industry, at a depth of $140 \mathrm{~cm}$. T15 sup (T15 upper) is the Laplace half-cut décapage corresponding to a depth of $140-144 \mathrm{~cm}$, so we selected bone samples for radiocarbon dating from within that half-cut décapage. In particular, we were especially keen to choose cutmarked identified bones so as to have as clear a link as possible to human activity. The use of caves by carnivores and bears in the Mousterian period is well known, so it was particularly important to avoid these species for samples from this period.

\section{2 - Radiocarbon AMS analysis}

The bones were sent to the Oxford Radiocarbon Accelerator Unit (ORAU) for all stages of the radiocarbon analysis by accelerator mass spectrometry (AMS). Pre-treatment, combustion, graphitization and measurement were done according to the current standard procedures for bones used in this laboratory. This included an ultrafiltration step which the ORAU deems to be an improvement to the thoroughness of eliminating contaminants, based on much research and experiments in recent years. For ample details regarding their techniques and procedures, the reader is invited to consult the following publications (Brock et al. 2007, 2010 ; Bronk-Ramsey et al. 2002, 2004a,b ; Brown et al. 1988 ; Higham et al. 2006 ; Jacobi et al. 2006 ; Wood et al. 2010). Eliminating contaminants is especially important in samples of Aurignacian/Mousterian age, where even a trace amount could significantly rejuvenate a date (Aitken 1990). None of the six samples has ever been coated in preservatives or consolidants and casts had not been made. They were photographed before submission for dating.

To summarize our approach to the dating of the Gatzarria collection, we did numerous studies before sampling, as outlined more amply above. Firstly, we carried out a complete techno-typological, raw material and surface condition study of the lithics from Cjn2 and Cjr. This showed homogeneity at the front of the cave, but not at the back, so we focused on the front. Secondly, for the front zone, we projected the lithic pieces bearing three-dimensional coordinates. This confirmed that layers touched each other and overlapped slightly within sedimentary unit $\mathrm{CJ}$. This also gave us general depth limits of layers, enabling us to select away from the contact surfaces between layers. Thirdly, we did refitting and conjoining work on the sampling zone being 
considered to check that there was no major vertical displacement there. Then, within these zone and depth constraints, we focused on selecting taxonomically identified bones in good condition, preferably with cutmarks. Furthermore, in terms of the laboratory aspects, we made sure that good pretreatment methods were applied to such Palaeolithic samples, including ultrafiltration, and we verified that chemical and elemental parameters were normal.

Table 6 - Provenience, taxonomic and human modification information of the AMS ${ }^{14} \mathrm{C}$-dated bones of Gatzarria Cave.

Tableau 6 - Provenance, détermination et types de modifications humaines des ossements datés par ${ }^{14} \mathrm{C}$ (SMA) de la grotte de Gatzarria.

\begin{tabular}{|c|c|c|c|c|c|c|c|c|c|}
\hline Site & Layer & Square & $\begin{array}{l}\text { Spatial and depth } \\
\text { information provided } \\
\text { by Laplace }\end{array}$ & $\begin{array}{c}\text { Associated } \\
\text { industry }\end{array}$ & $\begin{array}{l}\text { Provenience information } \\
\text { written on bone }\end{array}$ & $\begin{array}{l}\text { Sample designation } \\
\text { assigned in this study }\end{array}$ & Element/Taxon & Cutmarks & $\begin{array}{l}\text { Laboratory } \\
\text { number }\end{array}$ \\
\hline $\begin{array}{l}\text { Gatzarria } \\
\text { Gatzarria }\end{array}$ & $\begin{array}{l}\text { Cbf } \\
\text { Cbf }\end{array}$ & $3 \mathrm{~F}$ & $\begin{array}{l}\text { T4 (= } 30-40 \mathrm{~cm} \text { depth }) \\
\text { T4 (= }=30-40 \mathrm{~cm} \text { depth })\end{array}$ & $\begin{array}{c}\text { Classic } \\
\text { Aurignacian } \\
\text { Classic } \\
\text { Aurignacian }\end{array}$ & & $\begin{array}{l}\mathrm{GZ} \text { cbf } 3 \mathrm{~F} \mathrm{~T} 4 \# 1 \\
\mathrm{GZ} \text { cbf } 3 \mathrm{~F} T 4 \# 2\end{array}$ & $\begin{array}{c}\text { Long bone diaphysis } \\
\text { fragment: ungulate } \\
\text { size } 4 \\
\text { Long bone diaphysis } \\
\text { fragment: ungulate } \\
\text { size } 4\end{array}$ & yes & $\begin{array}{l}\text { OXA-22555 } \\
\text { OXA-22556 }\end{array}$ \\
\hline Gatzarria & Cjn2 & $3 E$ & $69.99 .95(\mathrm{z}, \mathrm{x}, \mathrm{y})$ & Proto-Aurignacian & G3E cj 69.99 .951 & GZ cjn2 3E 69.99.95 & $\begin{array}{l}\text { Left radius diaphysis } \\
\text { and proximal } \\
\text { epiphysis : Reindeer }\end{array}$ & & OXA-22553 \\
\hline Gatzarria & $\mathrm{Cjn} 2$ & $3 E$ & $78.25 .70(z, x, y)$ & Proto-Aurignacian & G3E cj 78.25 .70 & $G Z \operatorname{cjn} 23 E 78.25 .70$ & $\begin{array}{l}\text { Tibia diaphysis } \\
\text { fragment: Horse }\end{array}$ & yes & OxA-22554 \\
\hline $\begin{array}{l}\text { Gatzarria } \\
\text { Gatzarria }\end{array}$ & $\begin{array}{l}\mathrm{Cjr} \\
\mathrm{Cjr}\end{array}$ & $\begin{array}{l}3 \mathrm{~F} \\
3 \mathrm{~F}\end{array}$ & $\begin{array}{c}\text { T15 sup }(=140-144 \mathrm{~cm} \\
\text { depth) } \\
\text { T15 sup }(=140-144 \mathrm{~cm} \\
\text { depth) }\end{array}$ & $\begin{array}{l}\text { Vasconian } \\
\text { Mousterian } \\
\text { Vasconian } \\
\text { Mousterian }\end{array}$ & & $\begin{array}{l}\text { GZ cjr 3F (9) T15 sup \#1 } \\
\text { GZ cj } 3 F(9) \text { T15 sup \# } 2\end{array}$ & $\begin{array}{c}\text { Long bone diaphysis } \\
\text { fragment: Cervid } \\
\text { Metacarpal } \\
\text { diaphysis fragment : } \\
\text { Cervid }\end{array}$ & $\begin{array}{l}\text { yes } \\
\text { yes }\end{array}$ & $\begin{array}{l}\text { OXA-22557 } \\
\text { OXA-22558 }\end{array}$ \\
\hline
\end{tabular}

\section{5 - Results}

Results are quoted in radiocarbon years before present (BP) using the Libby $14 \mathrm{C}$ halflife and have been corrected for natural isotopic fractionation. The collagen yield percentage, as well as the elemental and isotopic values ( $\mathrm{C}: \mathrm{N}$, 熙13C, 臨15N) of all the samples are within normal parameters (tabl. 7) (Burleigh et al. 1984 ; DeNiro 1985 ; Hedges and van Klinken 1992 ; van Klinken 1999). The only exception is that the collagen yield percentage of one of the Mousterian samples (cjr 3F (9) T15 sup \#1) is low.

30 As can be seen, the dates are stratigraphically coherent, with some overlapping of dates. The two layer Cbf dates (Classic Aurignacian) are statistically identical to each other (overlap at one standard deviation). Within layer Cjn2 (Proto-Aurignacian), where we had precise depth measurements for the samples as opposed to simply square and décapage, the stratigraphically lower sample (cjn2 3E 78.25.70) is older than the stratigraphically higher sample (cjn2 3E 69.99.95). The Mousterian samples are also consistent, both being older than is possible to measure, being over $4740014 \mathrm{C} \mathrm{BP}$ in age.

\section{6 - Discussion}

31 In this section, we will place our new results in the larger context of issues of this period. We begin by reviewing the more salient points of debate of this period (section 6.1), then turn to the particular results obtained at Gatzarria to see the way in which they fit into these larger discussions (section 6.2). 


\section{1 - Background Middle to Upper Palaeolithic transition issues}

\subsection{1 - The early phases of the Aurignacian}

Table 7 - Radiocarbon, isotopic and elemental measurements on dated bones from Gatzarria. Radiocarbon dates are by accelerator mass spectrometry, expressed in uncalibrated radiocarbon years BP, using the Libby half-life, and have been corrected for isotopic fractionation. Stable isotope ratios are expressed in \% relative to the VPDB standard for carbon and the AIR standard for nitrogen.

Tableau 7 - Ensemble des mesures radiocarbones, isotopiques et élémentaires des ossements datés de Gatzarria. Les dates radiocarbone ont été faites par spectrométrie de masse par accélérateur. Elles sont exprimées en années BP non calibrées, ont été calculées en utilisant la valeur Libby de la demie-vie du carbone -14 et ont été corrigées pour le fractionnement isotopique. Les proportions des isotopes stables sont exprimées en \% en rapport avec le VPDB standard pour le carbone et le AIR standard pour l'azote.

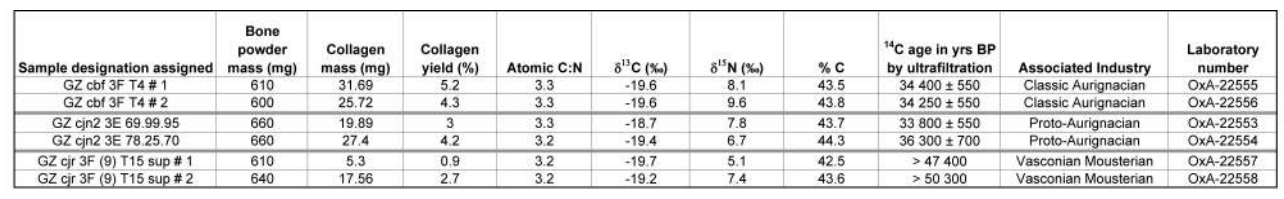

There has been much debate in recent years regarding the definition and characterization of the earliest Aurignacian industries, Proto-Aurignacian (Aurignacien archaïque) versus Classic Aurignacian (Early Aurignacian/Aurignacian I/Typical Aurignacian/Aurignacien ancien), and the techno-typological and chronological relationship between them. Until recently the Aurignacian (aside from its initial phases) was perceived by most scholars as a pan-European, homogeneous culture (for an overview see Bon 2002 ; Le Brun-Ricalens and Bordes 2007). In contrast, the ProtoAurignacian seemed more impoverished in terms of material culture and was mostly confined to the southern European zones.

The Proto-Aurignacian and Classic Aurignacian have been amply described elsewhere and the reader is invited to consult these works for detailed information (Arrizabalaga et al. 2009 ; Bazile 2005 ; Bazile and Sicard 1999 ; Bon 2002, 2006a and b; Bon et al. eds. 2006 ; Bordes 2005, 2006 ; Bordes et al. 2008 ; Broglio 1996 ; Chazan 2001 ; Conard and Bolus 2006 ; Kuhn and Stiner 1998 ; Laplace 1966b ; Le Brun-Ricalens 1993, 2005 ; Le Brun-Ricalens et al. 2009 ; Mellars 2006 ; Normand 2002 ; Normand and Turq 2005; Onoratini 1986, 2004 ; Teyssandier 2008).

In France, the Proto-Aurignacian is found primarily in the Mediterranean and Pyrenean regions and the number of chronometrically-dated ones is small. Even more rare are sites which contain both industries. In wanting to compare the ProtoAurignacian and Classic Aurignacian in terms of technology and typology, in order to assess their taxonomic relationship, and in wanting to assess their chronological relationship, such multi-stratified sites are of particular interest.

Based on evidence available until recently, it was usually thought that the ProtoAurignacian and Classic Aurignacian were separated geographically within Europe (Mediterranean Europe versus Central Europe/Atlantic region, respectively ; cf. note 3). Given the evidence available in these different regions, the question of their taxonomic and chronological relationship thus emerged.

Based on the few cases where the two industries have been found stratified in the same site, the Proto-Aurignacian is always underneath the Classic Aurignacian (Arrizabalaga et al. 2003, 2007, 2009 ; Bazile and Sicard 1999 ; Bon et al. in press ; Bordes 2006 ; Bordes et al. 2008 ; Eizenberg 2006 ; Kuhn and Stiner 1998 ; Laplace 1966b ; Laplace et al. eds. 
2006 ; Le Brun-Ricalens and Bordes 2007 ; Lhomme 1976 ; Normand et al. 2007 ; Onoratini 2004 ; Onoratini et al. 1999 ; Szmidt et al. 2010c; Talamo et al. 2012). In addition, chronometric dates on some Proto-Aurignacian assemblages in Italy, France and Spain indicated their existence potentially as far back as $38 \mathrm{ka} \mathrm{14C} \mathrm{BP} \mathrm{(Bischoff} \mathrm{et}$ al. 1989 ; Maíllo Fernandez et al. 2001). The Proto-Aurignacian was said to end around $34.7 \mathrm{ka} \mathrm{14C} \mathrm{BP} \mathrm{(Jöris} \mathrm{and} \mathrm{Street} \mathrm{2008).} \mathrm{Classic} \mathrm{Aurignacian} \mathrm{chronometric} \mathrm{dates} \mathrm{tended} \mathrm{to}$ fall in the 35-32 ka 14C BP range (Jöris and Street 2008). These two lines of evidence naturally led to the conclusion by some that the Proto-Aurignacian was older than the Classic Aurignacian (Bon 2002 ; Teyssandier 2006, 2008 ; Zilhão 2006) and that the two minimally overlapped in time (Jöris and Street 2008) ${ }^{2}$. For others, Proto-Aurignacian and Classic Aurignacian have been viewed as the material manifestations of not only two contemporaneous, but also separate human dispersals (Mellars 2004, 2006, 2009). Based on the technological differences between these industries, some have thus proposed reserving the term 'Aurignacian' only for the Classic Aurignacian, to reflect the fundamental differences between it and the Proto-Aurignacian and so as not to impose, a priori, an idea of a taxonomic link between them. Instead, names such as 'Fumanian' (Mellars 2006, 2009) or 'Mochian' (Bazile and Sicard 1999) have been offered to replace the term 'Proto-Aurignacian'.

Some more recent findings and studies, however, are making us re-evaluate these views. Regarding the chronological, geographic and/or taxonomic separation and independence of these two industries, a few cases have emerged of a technotypologically Proto-Aurignacian lithic industry associated with split-based points (Brou 1997 ; Liolios 2006 ; Schmider ed. 2002 ; Schmider and Perpère 1997 ; Soler Subils et al. 2008 ; Szmidt et al. 2010a). Until now, the latter were instead exclusively associated with the Classic Aurignacian. As well, Proto-Aurignacian assemblages are being found outside their 'expected' geographic range. Recent technological analyses of previously excavated assemblages and new excavations have revealed Proto-Aurignacian assemblages in southwestern and northern parts of France (Le Piage : Bordes 2002; Bordes et al. 2008 ; Les Cottés : Talamo et al. 2012 ; Grotte du Renne, level VII : Bon and Bodu 2002 ; Trou de la Mère Clochette : Brou 1997 ; Szmidt et al. 2010a), as well as in central Europe (Kozarnika level VII : Guadelli et al. 2005 ; Sirakov et al. 2007 ; Tsanova 2008 ; Krems and Tincova : Teyssandier 2006, 2008 ; Zilhão 2006). These demonstrate a geographical range which overlaps and even goes beyond that of the Classic Aurignacian.

Some of these Proto-Aurignacian assemblages have dates extending well into the range of the Classic Aurignacian (Szmidt et al. 2010a). In addition, there is evidence at some sites for in situ development of a Classic Aurignacian industry from Proto-Aurignacian roots, such as at Isturitz cave and possibly at other neighbouring Pyrenean sites (Arrizabalaga et al. 2009 ; Normand 2002 ; Normand et al. 2007 ; Szmidt et al. 2010c). This relationship and possible in situ transformation had also been proposed for the site of Gatzarria by Laplace (1966a) and is currently being re-evaluated by one of us (LE).

\subsection{2 - The Vasconian Mousterian}

39 The Vasconian was initially defined by Bordes (1953) as a regional Mousterian facies characterized by the presence of cleaver flakes, usually made from non-flint stone. Although this artifact is frequently found in the Acheulian, it disappears at the beginning of the Middle Palaeolithic. After that, it is only found in any significant 
number in a very restricted geographical region : the Basque area (Spain and France) and Cantabria.

In the 1970s and 1980s, as part of the larger culture-function debate challenging the Mousterian groupings of Bordes and the ethnic/cultural implications he attributed to them (see Szmidt 2003 for a detailed discussion of the Mousterian debate), a number of researchers (among them Cabrera Valdés 1983 ; Freeman, 1966, 1969-70) questioned the existence of the Vasconian as a separate facies. Based largely on typological evaluations and comparisons of Mousterian assemblages, they argued instead that it was simply a functional variant or even a normal part of the very heterogeneous nature of Mousterian assemblages in the Vasco-Cantabrian zone. Cabrera Valdés (1983) made the point that the Vasconian assemblages were very heterogeneous in terms of Bordes' typological and technical indices, which would argue against their unity as a separate entity.

41 It is difficult to defend the idea, however, that cleavers had a special function that could not have been served equally well by one of the other Mousterian tools. Use-wear data are only available on Acheulian quartzite and flint cleavers (and only on a very small sample), but they show that they were used on wood and meat (Utrilla and Mazo 1996), like many other Mousterian tools. A large-scale, interdisciplinary project is currently underway (Thiébaut ed. 2009) which includes use-wear analysis and experimentation aimed at discerning the possible function(s) of Mousterian cleavers.

In addition, a recent technological study of a number of Vasconian assemblages has found that they are united not simply by cleaver production and a high frequency of cleavers, but also by technological characteristics, including the use of the Discoid method for most lithic reduction and similar retouch type (Deschamps 2008, 2009). Further study is pending on a larger sample of assemblages (M. Deschamps, Ph.D. in progress), but it seems that their unity and their existence as a separate entity deserves to be reconsidered. Chronological unity would bolster such an argument. Dates so far on such sites indicate a late Mousterian attribution, with most being < 45000 and many $<40000$ BP (Allard 1993; Cabrera et al. 1996 ; Deschamps 2008; Maillo Fernandez et al. 2004 ; Mourre et al. 2005, 2006 ; Muñoz et al. 1989 ; Saenz de Buruaga and Ébrard 2004 ; Utrilla 2000). The Vasconian thus plays a key role in debates about late Neanderthal adaptations. If it is indeed a late industry, it could very well have overlapped in space and time with Aurignacian industries in the region.

\section{2 - Discussion of Gatzarria results in these larger debates}

As outlined in this paper, Gatzarria is an important site for three reasons regarding the Middle to Upper Palaeolithic transition. (1) It is a good case study into how to approach collections of excavations carried out before the benefit of taphonomic analyses for the purposes of conducting new analyses. It shows the great care that must be exercised, especially regarding chronometric sampling, if one is to minimize the risk of error that could easily otherwise go unnoticed if the initial excavation data were taken at face value ; (2) It is one of the few sites to contain a Vasconian Mousterian industry ; (3) It is among the few sites to contain a stratified sequence of Proto-Aurignacian and Classic Aurignacian levels. In this section, we will take each of these aspects in turn. 


\subsection{1 - Use of older excavations/collections for radiocarbon sampling}

\section{material excavated a while ago, depending on the type of question being asked and the} required precision. If a site contains a single component or the components are clearly distinguishable and physically far apart, it may be less critical to do a detailed stratigraphic assessment for the purposes of selecting samples to date. Dating of organic artifacts characteristic of a particular period can also make such an assessment less necessary.

clear at Gatzarria that selecting organic samples for dating based on the layer ascribed to them by Laplace would, depending on the square sampled, invariably lead to erroneous dates. The number could be very precise and could be correct in terms of measurement, but it would not relate to the event (human occupation layer) one thought one was dating (i.e. it would not be accurate). This is one of the major methodological points we hope to get across in this article. Due to the age of excavation, we wanted to verify the integrity of the stratigraphy and layer attributions before doing any sampling for dating. Recent controversies regarding the dating of other older collections revolve in part around this issue. We urge archaeologists sampling for dating in museum collections of older excavations to take this issue into account a priori. We are also in favour of using strict protocols to choose, clean and evaluate samples, as we have done here and on other sites (Langlais et al. 2010 ; Szmidt et al. $2009 \mathrm{a}, \mathrm{b}, 2010 \mathrm{a}, \mathrm{b}, \mathrm{c})$.

\subsection{2 - Vasconian Mousterian}

46 As mentioned, one of the key issues regarding the Vasconian is establishing its age. Dated sites until now have produced nearly exclusively recent dates $(<45000$, many $<$ $40000 \mathrm{BP}$ ). The new AMS 14C dates at Gatzarria, on cutmarked bones, help address this issue. According to these new dates ( $>47400$ and $>5030014 \mathrm{C} \mathrm{BP}$ ), this industry at Gatzarria is clearly not a terminal Mousterian overlapping with the Aurignacian. This result is consistent with the fact that this layer is separated from the Aurignacian ones by a Châtelperronian layer and another Mousterian layer. In other words, there is no evidence that the Vasconian Mousterian Neanderthals (presumed makers of the Vasconian ?) lived contemporaneously with 'Aurignacians' based on these results. They are clearly separated by at least 7-10 millenia. Whether it dates to MIS 3 (the period in which these infinite dates fall) or an older period, however, cannot be determined by these dates. It is important to realize, though, that these results do not preclude other Vasconian Mousterian sites from having been inhabited later (i.e. for the Vasconian to have overlapped the Aurignacian). Overall, the chronological period to which the Vasconian Mousterian is attributed differs depending on the data examined ; this is what may be causing controversy and uncertainty in its date. Radiocarbon evidence is pointing to a date around $40000 \mathrm{BP}$, taking into account many sites. The faunal spectrum identified at a number of Vasconian sites, however, is characteristic of a temperate climate, more likely attributable to MIS 5 according to some authors (Jaubert 2007). So either the Vasconian existed earlier than was thought (not only the end of the Mousterian), or the dates at $40 \mathrm{ka}$ BP from other sites need to be re-evaluated. New zooarchaeological work on a number of sites (Olha, Gatzarria) would provide new data on this debate. 
47 Answering these issues will require more dating of samples from multiple sites. It will also require the use of a variety of dating methods on samples bearing clear association to human occupation (an important aspect in Mousterian contexts given that those caves were also often used by carnivores or denning bears) and which come from zones that have clearly been established as largely undisturbed.

\subsection{3 - Proto-Aurignacian-Classic Aurignacian taxonomic and chronological relationship}

Regarding the Aurignacian, as outlined in section 6.1.1, one unresolved issue is whether the Proto-Aurignacian and the Classic Aurignacian are contemporary or not. Also, if they are contemporary, do they overlap substantially in time or only during a short time? Purely stratigraphically, including at Gatzarria, the Proto-Aurignacian is below the Classic Aurignacian. However, 1) the issue as to whether these industries may have been contemporaneous across adjacent regions (Atlantic/Mediterranean) remains unresolved and (2) we do not yet have a firm enough grasp of the period in question in the Atlantic zone, i.e. the very region in which one sometimes finds both industries present within a sequence. The small number of Proto-Aurignacian dates and the large standard deviation of many Aurignacian (sensu lato) dates make it difficult to evaluate their chronological relationship. The new chronometric dates at Gatzarria give us the opportunity to discuss these questions, including some important methodological aspects.

The stratigraphically lower Proto-Aurignacian sample (36300 $\pm 70014 \mathrm{C} \mathrm{BP}$ ) is in keeping (overlap at one standard deviation) with dates on Proto-Aurignacian layers in the overall region. These include dates from layer $\mathrm{C} 4 \mathrm{c} 4$ at the French Pyrenean site of Isturitz Cave (37 $180 \pm 420$ 14C BP) (Szmidt et al. 2010c), layer 8 of the northern Spanish sites of Cueva Morín (36 $590 \pm 770$ 14C BP) (Arrizabalaga et al. 2009 ; Maíllo et al. 2001) and La Viña layer XIII (36 $500 \pm 75014 \mathrm{C}$ BP, although also $31860 \pm 68014 \mathrm{C} \mathrm{BP}$ ) (Arrizabalaga et al. 2009). It overlaps at two standard deviations those of Castillo level 16 (34 $300 \pm 1000$ 14C BP) (Arrizabalaga et al. 2009 ; Cabrera Valdés et al. 2002), the layer $\mathrm{H}$ dates from the eastern Pyrenean site of Arbreda Cave (average of $38300 \pm 50014 \mathrm{C} \mathrm{BP}$ ) (Bischoff et al. 1989 ; Soler Subils et al. 2008) and Abric Romaní layer A (Camps and Higham 2012) ${ }^{3}$.

Looking further afield, this Gatzarria date is older than, or is statistically equivalent to, other Proto-Aurignacian dates. These include the new AMS radiocarbon dates on charcoal at Fumane level A2 (Higham et al. 2009), the dates of the deeper part of Mochi level G (Douka et al. 2012 ; Kuhn and Stiner 1998), Paglicci 24Bi (Palma di Cesnola 1999 ; Riel-Salvatore and Negrino 2009), the recently done dates of Grotte du Renne level VII (Higham et al. 2010) and Les Cottés Unit 04 lower (Talamo et al. 2012), as well as the conventional radiocarbon dates at Esquicho-Grapaou SLC1 (Bazile and Sicard 1999 ; Delibrias and Evin 1980). It is important to note that although many of these others appear to be younger than Gatzarria when only comparing the date itself, the situation is not so clear when we take into account, as one should, the standard deviations (overlap at one or two standard deviations). On the other hand, it is also true that other assemblages ascribed to the Proto-Aurignacian in Italy (Cala, Castelcivita, Serino) appear much younger than Gatzarria according to their dates (Riel-Salvatore and Negrino 2009), even if we take into account the standard deviations (no overlap even at two standard deviations). The recently obtained AMS dates on the Proto-Aurignacian at 
Serino, however, are much older than its conventional radiocarbon date (especially the dates done using the ABOx-SC protocol) (Wood et al. 2012).

51 New dating on some of these assemblages/sites may need to be done in light of new archaeological and laboratory methodological advances in dating. Also, importantly, establishing whether all of these assemblages truly belong to the same industrial complex as Cjn2 requires re-assessment using identical criteria and methods of definition. The extent of variability within what has been termed 'Proto-Aurignacian' is not yet known, many of these assemblages having been examined prior to recent technological definitions of this industry. Thus it is important to remember that these assemblages may not be strictly comparable, nor accurate in their dates ; conclusions may change in the near future in light of new analyses.

52 At the other end, the dates of layer Cbf at Gatzarria (Classic Aurignacian) (34 $250 \pm 550$ and $34400 \pm 55014 \mathrm{C} \mathrm{BP}$ ) are statistically equivalent and are in accordance with the older Classic Aurignacian dates of the neighbouring and recently-dated site of Brassempouy (layers 2F and 2DE) (Fontugne in Henry-Gambier D. and Bon F. eds., in preparation). They are also on the older end of many Classic Aurignacian sites in the Dordogne region and other neighbouring regions (Arrizabalaga et al. 2009 ; Jöris and Street 2008 ; Mellars 2000 ; Talamo et al. 2012 ; Zilhão et al. 2008). These dates are as old, or older, than some of those obtained for the Proto-Aurignacian in southeastern France and Italy.

Gatzarria can also contribute to the idea that the Proto-Aurignacian and the Classic Aurignacian may have been contemporaneous on the macro-regional western European scale. Indeed, the stratigraphically higher Gatzarria Cjn2 sample is clearly younger than the stratigraphically lower Cjn2 sample, but also overlaps some recentlydated Proto-Aurignacian sites, such as one of the two dates from Trou de la Mère Clochette (Szmidt et al. 2010a). Both the Gatzarria and Trou de la Mère Clochette dates were obtained very recently, by the same laboratory and both had the ultrafiltration step as part of their pre-treatment. It seems then, that the Proto-Aurignacian lasted until later than has been argued based on dates available until now, enduring until at least sometime around 33350 to 34350 14C BP (taking the one standard deviation ranges of Gatzarria (cjn2 3E 69.99.95) and Trou de la Mère Clochette sample \#2). In other words, it seems to have lasted into the chronological range of Classic Aurignacian sites, an industry which is generally thought to have been present across Europe by 35 ka 14C BP (Jöris and Street 2008). In other words, they may have been contemporaneous between sites or regions ${ }^{4}$.

Until recently, young dates in the Aurignacian (both the Proto-Aurignacian and Classic Aurignacian) may have been more likely caused by a small amount of more recent contamination not having been fully removed during pre-treatment. Based on recent research done, ultrafiltration seems to reduce this risk by eliminating lower weight molecules likely to be potential contaminants or degraded collagen (Brock et al. 2007 ; Bronk Ramsey et al. 2004a ; Higham et al. 2006 ; Jacobi et al. 2006). This hypothesis of a later-lasting Proto-Aurignacian still needs to be confirmed from a larger number of recently-dated sites to bolster the argument of the pattern seen so far. Those of Les Cottés Unit 04 lower, also done using ultrafiltration, show similar results (Talamo et al. 2012).

55 At Isturitz Cave, also located in the Pyrenean region (fig. 1, \#9), and also bearing both industries in its stratigraphic sequence, there is evidence that an in situ transformation 
from Proto-Aurignacian to Classic Aurignacian might have occurred in layer $\mathrm{C} 4 \mathrm{c} 4$, dated to $37180 \pm 420{ }^{14} \mathrm{C}$ BP (thus $38020-36340 \mathrm{BP}$, at two SD) (Szmidt et al. 2010c). At Gatzarria, the occurrence of the changeover is seen a bit later. Whether we are witnessing a replacement or instead an in situ transformation at Gatzarria has yet to be determined through detailed re-examination of the Cbf material in the way in which Cjn1 and Cjn2 have been re-analyzed. In any case, at Gatzarria, based on the dates produced by these samples, this would have occurred sometime between 34900 and 33 300 BP (fig. 10).

To sum up, the results obtained at Gatzarria indicate the presence of the ProtoAurignacian in the Atlantic zone at least as early as in regions East of it, judging by the date on the deeper Cjn2 sample (36 $300 \pm 700$ 14C BP). As mentioned above, this date fits perfectly with other Proto-Aurignacian dates of the region. The Gatzarria results also show that the Classic Aurignacian may have developed earlier than usually suspected, possibly prior to $34000 \mathrm{BP}$ judging by the two statistically equivalent dates obtained for Cbf (34 $250 \pm 550$ and $34400 \pm 550$ 14C BP). Do these observations allow us to conclude not only that the Proto-Aurignacian began at least as early in the Atlantic zone as in the Mediterranean zone, but also that it ended earlier in the former, giving way to the Classic Aurignacian earlier than in the latter region? As discussed above, these results do not help resolve the issue of contemporaneity - we do not yet know the precise timing of the change from one facies to the other, given that the dates of the two facies overlap. Redating Proto-Aurignacian sites using more modern cleaning, measurement and archaeological selection techniques (as is being done in this larger dating project), would help to resolve this issue, given that it often leads to improved precision (smaller standard deviations) and accuracy.

Figure 10 - Graphical representation of the Cjn2 and Cbf dates. For each date, the two standard deviation range is shown by a horizontal line and in numerical form.

Figure 10 - Représentation graphique des datations de Cjn2 et de Cbf. Chaque date est présentée à deux écarts-types, en chiffres et par un trait horizontal.

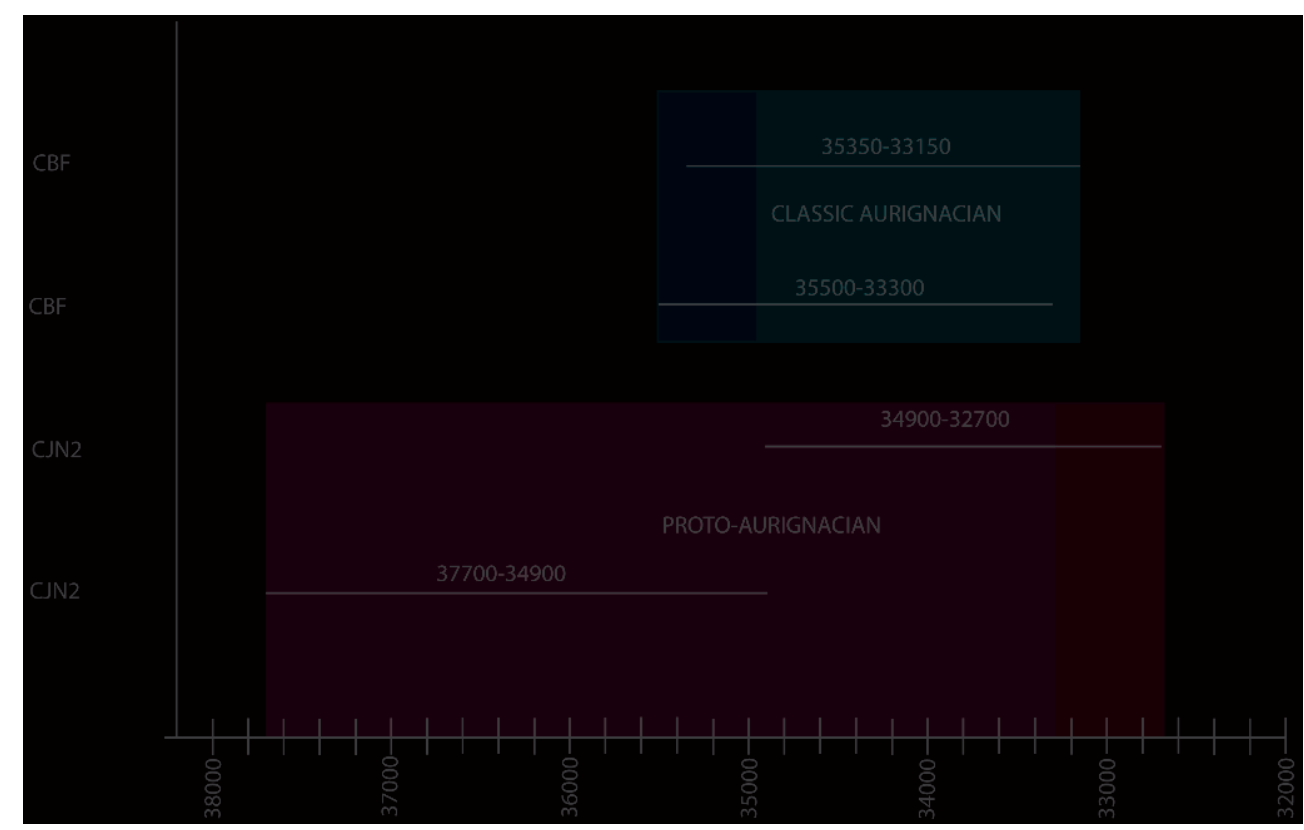

We are very grateful to the Executor of the G. Laplace estate, the late F. Lévêque, as well as to J.-J. Cleyet-Merle, Curator of the Musée National de Préhistoire (Les Eyzies-de-Tayac, France) for 
having granted us permission to study and sample the collection from Gatzarria. All of the staff at the Musée National de Préhistoire helped to make our stay welcoming and our access and work on the samples efficient and productive. In particular, we wish to express our thanks to Stéphane Madelaine for having carried out the taxomonic identification of the dated bones and to Philippe Jugie for having taken photographs of the bones prior to their dating. We also wish to thank the staff of the ORAU for their work. François Bon and three reviewers read an earlier draft of this paper and provided some very good comments, for which we are grateful.

\section{BIBLIOGRAPHY}

AITKEN M. J. 1990 - Science-based dating in archaeology. London : Longman, 296 p.

ALLARD M. 1993 - Fréchet-Aure, Grotte du Noisetier, Bilan scientifique 1992 de la Direction Régionale des Affaires Culturelles de Midi-Pyrénées, Ministère de la Culture.

ARRIZABALAGA A., ALTUNA J., ARESO P., ELORZA M., GARCÍA M., IRIARTE M.J., MARIEZKURRENA K., MUJIKA J., PEMÁN E., TARRI-O A., URIZ A., VIERA L., STRAUS L.G. 2003 - The Initial Upper Paleolithic in Northern Iberia : New evidence from Labeko Koba. Current Anthropology, 44, 3, p. 413-421.

ARRIZABALAGA A., BERNALDO DE QUIRÓS F., BON F., IRIARTE M.-J., MAÍlLO J.-M., NORMAND C. 2009 - Early evidence of the Aurignacian in Cantabrian Iberia and the North Pyrenees. In : M. Camps, C. Szmidt (Eds.), The Mediterranean from 50000 to 25000 B.P. : turning points and new directions. Oxford, Oxbow Books, p. 255-292.

ARRIZABALAGA A., BON F., MAÍLLO-FERNANDEZ J. M., NORMAND C., ORTEGA I. 2007 - Territoires et frontières de l'Aurignacien dans les Pyrénées occidentales et les Cantabres. In : N. Cazals, J. G. Urquijo, X. Terradas (Eds.), Terradas, fronteras naturales y fronteras culturales en los Pireneos prehistoricos. Santader, Universidad de Cantabria, p. 301-318.

BAZILE F. 2005 - La composante lamellaire dans l'Aurignacien initial de la France méditerranéenne. In : F. Le Brun-Ricalens, J.-G. Bordes, F. Bon (Eds.), Productions lamellaires attribuées à l'Aurignacien: chaînes opératoires et perspectives technoculturelles. Luxembourg, Musée National d'Histoire et d'Art, p. 325-336 (ArchéoLogiques, 1).

BAZILE F., SICARD S. 1999 - Le premier Aurignacien du Languedoc oriental dans son contexte méditerranéen. In : D. Sacchi (Ed.), Les faciès leptolithiques du nord-ouest méditerranéen : milieux naturels et culturels. XXIVè Congrès Préhistorique de France, 1994. Carcassonne, Société Préhistorique Française, p. 117-125.

BISCHOFF J.L., SOLER N., MAROTO J., JULIÀ R. 1989 - Abupt Mousterian/Aurignacian boundary at c. $40 \mathrm{ka} \mathrm{bp}$ : Accelerator $14 \mathrm{C}$ dates from l'Arbreda cave (Catalunya, Spain). Journal of Archaeological Science, 16, p. 563-576.

BON F. 2002 - L'Aurignacien entre mer et océan - réflexion sur l'unité des phases anciennes de l'Aurignacien dans le sud de la France. Paris : Société Préhistorique Française, Mémoire 29, 253 p. BON F. 2006a - A brief overview of Aurignacian cultures in the context of the industries of the transition from the Middle to the Upper Paleolithic. In : O. Bar-Yosef, J. Zilhão (Eds.), Towards a 
definition of the Aurignacian. Lisbon, Instituto Português de arqueologia, p. 133-144 (Trabalhos de Arqueologia 45).

BON F. 2006b - Les termes de l'Aurignacien. In : F. Bon, J.M. Maíllo Fernández, D. Ortega Cobos (Eds.), En torno a los conceptos de Protoauriňaciense, Auriňaciense arcaico, inicial y antiguo (unidad y variabilidad de los comportamientos tecnológicos de los primeros grupos de humanos modernos en el sur de Francia y norte de Espaňa), Actes de la Table-ronde de Toulouse, 2003. Espacio, Tiempo y Forma, Serie I, 2002 (2006), p. 39-65 (Prehistoria y Arqueología, 15)

BON F., BODU P. 2002 - Analyse technologique du débitage aurignacien. In : B. Schmider (Ed.), L'Aurignacien de la grotte du Renne. Les fouilles d'André Leroi-Gourhan à Arcy-sur-Cure (Yonne). GalliaPréhistoire, XXXIV ${ }^{\circ}$ supplément, Ed. du CNRS, p. 115-133.

BON F., MAÍLLO FERNANDEZ J.-M., ORTEGA COBOS D. (Eds.) 2006 - Autour des concepts de Protoaurignacien, d'Aurignacien initial et ancien : unité et variabilité des comportements techniques des premiers groupes d'Hommes modernes dans le sud de la France et le nord de l'Espagne. Actes de la table-ronde (2003). Espacio, Tiempo y Forma, Serie I. Toulouse, Girona, Madrid : Université de Toulouse le Mirail, 262 p. (Prehistoria y Arqueologia, 15).

BON F., PELEGRIN J., O'FARRELL M., PRIMAULT J., TARRI-O A. In press - Les industries châtelperroniennes et aurignaciennes de la grotte des Hyènes et de l'abri Dubalen. In : D. HenryGambier, F. Bon (Eds.), L'Aurignacien ancien de la grotte des Hyènes (Brassempouy, Landes). Paris, éditions du CNRS, suppl. à Gallia-Préhistoire.

BORDES F. 1953 - Essai de classification des industries "moustériennes". Bulletin de la Société Préhistorique Française, 50, p. 457-466.

BORDES J.-G. 2002 - Les interstratifications Châtelperronien / Aurignacien du Roc-de-Combe et du Piage (Lot, France). Analyse taphonomique des industries lithiques; implications archéologiques. Bordeaux : Université Bordeaux I, 420 p. Doctoral thesis.

BORDES J.-G. 2005 - La séquence aurignacienne du nord de l'Aquitaine : variabilité des productions lamellaires à Caminade-Est, Roc-de-Combe, Le Piage et Corbiac-Vignoble II. In : F. Le Brun-Ricalens, J.-G. Bordes, F. Bon (Eds.), Productions lamellaires attribuées à l'Aurignacien : chaînes opératoires et perspectives technoculturelles. Luxembourg, Musée National d'Histoire et d'Art, p. 123-154 (ArchéoLogiques, 1).

BORDES J.-G. 2006 - News from the West : a reevaluation of the classical Aurignacian sequence of the Périgord. In : O. Bar-Yosef, J. Zilhão (Eds.) Towards a definition of the Aurignacian. Lisbon, Instituto Português de arqueologia, p. 147-171 (Trabalhos de Arqueologia 45).

BORDES J.-G., LE BRUN-RICALENS F., CASTEL J.-C., DUCASSE S., FAIVRE J.-P., FERUGLIO V., HENRIGAMBIER D., LACRAMPE-CUYAUBÈRE F., LAROULANDIE V., LENOBLE A., MARTIN H., MAUREILLE B., MORALA A., MORIN E., RENARD C., RENDU W., RIGAUD S., ROUGIER H., SZMIDT C., TARTAR E., TEYSSANDIER N., TEXIER J.-P. 2008 - Les débuts du Paléolithique supérieur dans le sud-ouest de la France : nouvelles fouilles au Piage (2004-2006). Problématique et premiers résultats. In : J.

Jaubert, J.-G. Bordes, I. Ortega (Eds.), Les sociétés du Paléolithique dans un grand sud-ouest de la France : nouveaux gisements, nouveaux résultats, nouvelles méthodes. Paris, Société Préhistorique Française, Mémoire 47, p. 261-288.

BROCK F., BRONK RAMSEY C., HIGHAM T. 2007 - Quality assurance of ultrafiltered bone dating. Radiocarbon, 49, 2, p. 187-192.

BROCK F., HIGHAM T., DITCHFIELD P., BRONK RAMSEY C. 2010 - Current pretreatment methods for AMS radiocarbon dating at the Oxford Radiocarbon Accelerator Unit (ORAU). Radiocarbon, 52, 1, p. 103-112. 
BROGLIO A. 1996 - The appearance of modern humans in Europe : the archaeological evidence from the Mediterranean regions. In : O. Bar-Yosef, L. L. Cavalli-Sforza, R. J. March, M. Piperno (Eds.), The Lower and Middle Palaeolithic. Proceedings of the 13th UISPP congress, vol. 5. Forlì, A.B.A.C.O., p. 237-249.

BRONK RAMSEY C., HIGHAM T. F. G., OWEN D. C., PIKE A. W. G., HEDGES R. E. M. 2002 -

Radiocarbon dates from the Oxford AMS system : Archaeometry datelist 31. Archaeometry, 44, 3, Supplement 1, p. 1-149.

BRONK RAMSEY C., HIGHAM T., BOWLES A., HEDGES R. 2004a - Improvements to the pretreatment of bone at Oxford. Radiocarbon, 46, 1, p. 155-163.

BRONK RAMSEY C., HIGHAM T., LEACH P. 2004b - Towards high-precision AMS : progress and limitations. Radiocarbon, 46, 1, p. 17-24.

BROU L. 1997 - L'industrie aurignacienne du "Trou de la Mère Clochette" à Rochefort-sur-Neron, Jura. Présentation des données. In, Le Paléolithique supérieur de l'Est de la France : de l'Aurignacien à l'Ahrensbourgien. Actes du colloque de Chaumont, 1994. Reims, Mémoire de la Société Archéologique Champenoise, 13, supplément au Bulletin 2, p. 15-35.

BROWN T.A., NELSON D.E., VOGEL J.S., SOUTHON J.R. 1988 - Improved collagen extraction by modified Longin method. Radiocarbon, 30, 2, p. 171-177.

BURLEIGH R., MATTHEWS K., LEESE M. 1984 - Consensus d 13C values. Radiocarbon, 26, 1, p. 46-53.

CABRERA VALDÉS V. 1983 - Notas sobre el Musteriense cantábrico : el 'Vasconiense'. Homenaje al Prof. Martín Almagro Basch I. Ministerio de Cultura, p. 131-141.

CABRERA VALDÉS V., BERNALDO DE QUIROS F., VALLADAS H., LLORET M., MAÍLLO FERNANDEZ J.M. 2002 - El Auriñaciense arcaico de El Castillo (Cantabria) : descripción tecnológica y objetivos de la producción. In : F. Bon, J. M. Maíllo-Fernández, D. Ortega (Eds.), Autour des concepts de Protoaurignacien, d'Aurignacien initial et ancien : unité et variabilité des comportements techniques des premiers groupes d'Hommes modernes dans le sud de la France et le nord de l'Espagne. Actes de la tableronde (2003). Espacio, Tiempo y Forma, Serie I. Toulouse, Girona, Madrid : Université de Toulouse le Mirail, p. 67-86 (Prehistoria y Arqueologia, 15).

CABRERA VALDÉS V., VALLADAS H., BERNALDO DE QUIROS F., HOYOS GOMEZ M. 1996 - La transition Paléolithique moyen - Paléolithique supérieur à El Castillo, Cantabrie : nouvelles datations par le carbone-14. Comptes Rendus de l'Académie des Sciences de Paris, 322, p. 1093-1098.

CAHEN D., MOEYERSONS J. 1977 - Subsurface movements of stone artefacts and their implications for the prehistory of central Africa. Nature, 266, p. 812-815.

CAMPS M., HIGHAM T. 2012 - Chronology of the Middle to Upper Palaeolithic transition at Abric Romaní, Catalunya. Journal of Human Evolution, 62, p. 89-103.

CHAZAN M. 2001 - Bladelet production in the Aurignacian of La Ferrassie (Dordogne, France). Lithic Technology, 26, 1, p. 16-28.

CONARD N.J., BOLUS M. 2006 - The Swabian Aurignacian and its place in European prehistory. In : O. Bar-Yosef, J. Zilhão (Eds.), Towards a definition of the Aurignacian. Lisbon, Instituto Português de arqueologia, p. 211-239 (Trabalhos de Arqueologia 45).

CZIESLA E., EICKHOFF S., ARTS N., WINTER D. 1990 - The big puzzle, international symposium on refitting stone artefacts. 1987. Bonn : Monrepos, Studies in Modern Archaeology 1, 683 p.

DELIBRIAS G., EVIN J. 1980 - Sommaire des datations $14 \mathrm{C}$ concernant la préhistoire en France II. Dates parues de 1974 à 1978. Bulletin de la Société Préhistorique Française, 77, 7, p. 215-224. 
DEMARS P.-Y., LAURENT P. 1989 - Types d'outils lithiques du Paléolithique supérieur en Europe. Paris : CNRS, Cahiers du Quaternaire 14.

DENIRO M.J. 1985 - Postmortem preservation and alteration of in vivo bone collagen isotope ratios in relation to palaeodietary reconstruction. Nature, 317, p. 806-809.

DESCHAMPS M. 2008 - Le Vasconien et sa signification au sein des faciès moustériens. Toulouse : Université de Toulouse-Le Mirail, Master II thesis.

DESCHAMPS M. 2009 - Le Vasconien : Révision de sa signification à partir des industries d'Olha I et II, d'Isturitz et de Gatzarria, Paléo, 21, 101-126.

DOUKA K., GRIMALDI S., BOSCHIAN G., DEL LUCCHESE A., HIGHAM. T.F.G. 2012 - A new chronostratigraphic framework for the Upper Palaeolithic of Riparo Mochi (Italy). Journal of Human Evolution 62, p. 286-299.

EIZENBERG L. 2006 - Le rôle de l'Aurignacien archaïque dans les phases initiales du Paléolithique supérieur : apports des industries lithiques de la grotte des Abeilles (Haute-Garonne). Toulouse : Université de Toulouse Le Mirail, Master II thesis.

FREEMAN L.G. 1966 - The nature of Mousterian facies in Cantabrian Spain. American Anthropologist, p. 230-237.

FREEMAN L.G. 1969-70 - El Musteriense cantábrico : Nuevas perspectivas. Ampurias, 31-32, p. 55-69.

GUADELLI J.-L., SIRAKOV N., IVANOVA ST, SIRAKOVA SV, ANASTASSOVA E., COURTAUD P., DIMITROVA I., DJABARSKA N., FERNANDEZ P., FERRIER C., FONTUGNE M., GAMBIER D., GUADELLI A., IORDANOVA D., IORDANOVA N., KOVATCHEVA M., KRUMOV I., LEBLANC J.-C., MALLYE J.-B., MARINSKA M., MITEVA V., POPOV V., SPASSOV R., TANEVA S., TISERAT-LABORDE N., TSANOVA T. 2005 - Une séquence du Paléolithique inférieur au Paléolithique récent dans les Balkans : La grotte de Kozarnika à Orechets (nord-ouest de la Bulgarie). In : N. Molines, M.-H. Moncel, J.-L. Monnier (Eds.), Les premiers peuplements en Europe. Oxford, British Archaeological Reports, Volume 1364 , p. $87-103$.

HEDGES R.E.M., VAN KLINKEN G.J. 1992 - A review of current approaches in the pretreatment of bone for radiocarbon dating by AMS. Radiocarbon 34, 3, p. 279-291.

HENRY-GAMBIER D., BON F. (Eds) in preparation - L'Aurignacien ancien de la grotte des Hyènes (Brassempouy, Landes). Paris, éditions du CNRS, suppl. à Gallia Préhistoire (with the collaboration of E. Desclaux, M.-F. Diot, C. Ferrier, M. Fontugne, Ph. Gardère, C. Letourneux, B. Maureille, R. Mensan, M. O’Farell, J. Pelegrin, J.-M. Pétillon, Y. Potin, J. Primault, V. Richard, A. Tarriño, E. Tartar, R. White).

HIGHAM T., BROCK F., PERESANI M., BROGLIO A., WOOD. R., DOUKA K. 2009 - Problems with radiocarbon dating the Middle to Upper Palaeolithic transition in Italy. Quaternary Science Reviews, 28, p. 1257-1267.

HIGHAM. T., JACOBI. R.M., BRONK RAMSEY. C. 2006 - AMS radiocarbon dating of ancient bone using ultrafiltration. Radiocarbon 48, 2, p. 179-195.

HIGHAM T., JACOBI R., JULIEN M., DAVID F., BASELL L., WOOD R., DAVIES W., BRONK RAMSEY C. 2010 - Chronology of the Grotte du Renne (France) and implications for the context of ornaments and human remains within the Châtelperronian. Proceedings of the National Academy of Sciences USA, 107, 47, p. 20234-20239.

HOFMAN J. L. 1986 - Vertical movement of artifacts in alluvial and stratified deposits. Current Anthropology, 27, 2, p. 163-171. 
JACOBI R.M., HIGHAM T.F.G., BRONK RAMSEY C. 2006 - AMS radiocarbon dating of Middle and Upper Palaeolithic bone in the British Isles : improved reliability using ultrafiltration. Jounal of Quaternary Science, 21, 5, p. 557-573.

JAUBERT J. 2007 - Quels peuplements avant l'Aurignacien sur le versant nord des Pyrénées ? Qui est l'Aurignacien? Aurignac, Éditions Musée-forum cahier 3, p. 9-25.

JÖRIS O., STREET M. 2008 - At the end of the 14C time scale 皫the Middle to Upper Paleolithic record of western Eurasia. Journal of Human Evolution, 55, p. 782-802.

KUHN S.L., STINER M.C. 1998 - The earliest Aurignacian of Riparo Mochi (Liguria, Italy). Current Anthropology 39, Supplement 3, p. S175-S189.

LANGLAIS M., PÉTILLON J.-M, DE BEAUNE S.A., CATTELAIN P., CHAUVIÈRE F.-X., LETOURNEUX C., SZMIDT C., BELLIER C., BEUKENS R., DAVID F. 2010 - Une occupation de la fin du dernier maximum glaciaire dans les Pyrénées : le Magdalénien inférieur de la grotte des Scilles (Lespugue, Haute-Garonne). Bulletin de la Société Préhistorique Française 107, 1, p. 5-51.

LAPLACE G. 1962 - Grotte Gatzarria, Commune d'Ossas-Suhare (Basses-Pyrénées). Rapport de fouilles, Archives du Musée National de Préhistoire des Eyzies-de-Tayac, 8 p.

LAPLACE G. 1963 - Grotte Gatzarria, Commune d'Ossas-Suhare (Basses-Pyrénées). Rapport de fouilles, Archives du Musée National de Préhistoire des Eyzies-de-Tayac, 5 p.

LAPLACE G. 1966a - Recherches sur l'origine et l'évolution des complexes leptolithiques. Paris : Mélanges d'Archéologie et d'Histoire, École française de Rome, $4^{\circ}$ supplément, 586 p.

LAPLACE G. 1966b - Les niveaux Castelperronien, Protoaurignaciens et Aurignaciens de la Grotte Gatzarria à Suhare en Pays Basque (fouilles 1961-1963). Quartär, p. 117-140.

LAPLACE G. 1971 - De l'application des coordonnées cartésiennes à la fouille stratigraphique. Munibe, (2/3), p. 223-236.

LAPLACE G., MÉROC L. 1954 - Application des coordonnées cartésiennes à la fouille d'un gisement. Bulletin de la Société Préhistorique Française, 51, 1-2, p. 58-66.

LAPLACE G., SAENZ DE BURUAGA A. 2002 - Typologie analytique et structurale des complexes Moustérien de la grotte de Gatzarria (Ossa-Suhare, Pays Basque) et de leurs relations avec ceux de l'abri Olha 2 (Cambo, Pays Basque). Pyrenae, 33-34, p. 81-163.

LAPLACE G., BARANDIARAN I., SAENZ DE BURUAGA A., ALTUNA J. (Eds.) 2006 - Les Aurignaciens pyrénéen des Abeilles et méditerranéen de Régismont-le-Haut, Analyses typologique et paléontologique. Les Eyzies-de-Tayac : Dordogne, SAMRA, 154 p.

LAVAUD F. 1980 - Les faunes paléolithiques du Würm II et III dans le sud-ouest et le centre-ouest de la France. Poitiers : Université de Poitiers, 319 p., Doctoral thesis.

LE BRUN-RICALENS F. 1993 - Réflexions préliminaires sur le comportement litho-technologique et l'occupation du territoire du Pays des Serres à l'Aurignacien : Le gisement de 'Toulousète' à Beauville (Lot-et-Garonne), une occupation moustérienne et aurignacienne de plein air. Paléo, 5, p. 127-153.

LE BRUN-RICALENS F. 2005 - Reconnaissance d'un “concept technoculturel” de l'Aurignacien ancien? Modalités, unités et variabilités des productions lamellaires du site d'Hui (Beauville, Lotet-Garonne, France) : significations et implications. In : F. Le Brun-Ricalens, J.-G. Bordes, F. Bon (Eds.), Productions lamellaires attribuées à l'Aurignacien : chaînes opératoires et perspectives technoculturelles. Luxembourg, Musée National d'Histoire et d'Art, p. 23-72 (ArchéoLogiques, 1). 
LE BRUN-RICALENS F., BORDES J.-G. 2007 - Les débuts de l'Aurignacian en Europe occidentale : unité ou diversité ? Du territoire de subsistance au territoire culturel. Die Anfänge des Aurignacien in Westeuropa : Einheit oder Diversität? Vom Subsistenzraum zur Kulturlandschaft. In : H. Floss, N. Rouquerol (Eds.), Les chemins de l'Art aurignacien en Europe. Das Aurignacien und die Anfänge der Kunst in Europa. Actes du colloque international d'Aurignac, 16-18 sept. 2005. Toulouse, Editions Musée-Forum Aurignac, p. 37-62 (Cahier 4).

LE BRUN-RICALENS F., BORDES J.-G., EIZENBERG L. 2009 - A crossed-glance between southern European and Middle-Near Eastern early Upper Palaeolithic lithic technocomplexes : Existing models, new perspectives. In : M. Camps, C. Szmidt (Eds.), The Mediterranean from 50000 to 25000 B.P.: turning points and new directions. Oxford, Oxbow Books, p. 11-34.

LÉVÊQUE F. 1966 - La grotte Gatzarria de Suhare, Basses Pyrénées, Étude sédimentologique et archéologique. Poitiers : Faculté des Sciences de Poitiers, DES, $121 \mathrm{p}$.

LÉVÊQUE F., MISKOVSKY J.-C. 1993 - Le passage du Paléolithique moyen au Paléolithique supérieur dans la grotte Gatzarria de Suhare : données sédimentologiques et comparaisons. Pau, Congrès National des Sociétés Historiques et Scientifiques 118 , p. 41-60.

LHOMME G. 1976 - Un nouveau gisement paléolithique en Ardèche : L'abri des Pêcheurs à Casteljau. Études Préhistoriques, 13, p. 1-8.

LIOLIOS D. 2006 - Reflections on the role of bone tools in the definition of the Early Aurignacian. In : O. Bar-Yosef, J. Zilhão (Eds.), Towards a definition of the Aurignacian. Lisbon, Instituto Português de arqueologia, p. 37-51 (Trabalhos de Arqueologia 45).

MAÍLLO FERNANDEZ J.M., VALLADAS H., CABRERA VALDÈS V., BERNALDO DE QUIRÓS F. 2001 Nuevas dataciones para el Paleolítico superior de Cueva Morin (Villanueva de Villaescusa, Cantabria). Espacio, Tiempo y Forma, Serie I, p. 145-150 (Prehistoria y Arqueologia, 14).

MAÍLLO FERNANDEZ J. M., CABRERA VALDÉS V., BERNALDO DE QUIRÓS F. 2004 - Le débitage lamellaire dans le Moustérien final de Cantabrie (Espagne) : le cas de El Castillo et de Cueva Morin. L'Anthropologie, 108, p. 367-393.

MELLARS P. 2000 - The archaeological records of the Neandertal-modern human transition in France. In : O. Bar-Yosef, D. Pilbeam (Eds.), The geography of Neandertals and modern humans in Europe and the greater Mediterranean. Cambridge, Peabody Museum Bulletin 8, p. 35-47.

MELLARS P. 2004 - Neanderthals and the modern human colonization of Europe. Nature, 432, p. 461-465.

MELLARS P. 2006 - Archeology and the dispersal of modern humans in Europe : deconstructing the 'Aurignacian'. Evolutionary Anthropology, 15, p. 167-182.

MELLARS P. 2009 - La confusion aurignacienne : Disentangling the archaeology of modern human dispersals in Europe. In : M. Camps, C. Szmidt (Eds.), The Mediterranean from 50000 to 25000 B.P.: turning points and new directions. Oxford, Oxbow Books, p. 339-356.

MOURRE V., COLONGE D., COSTAMAGNO S., CRAVINHO S., MAUREILLE B., NICLOT M., THIÉBAUT C., VIGUIER J. 2005 - Le site moustérien de la Grotte du Noisetier à Fréchet-Aure (Hautes-Pyrénées), Premier rapport intermédiaire, Fouille programmée pluriannuelle 2005-2007.

MOURRE V., BRUXELLES L., COSTAMAGNO S., CRAVINHO S., RENVOISÉ É., THIÉBAUT, C., VIGUIER J. 2006 - Le site moustérien de la Grotte du Noisetier à Fréchet-Aure (Hautes-Pyrénées), Deuxième rapport intermédiaire, Fouille programmée pluriannuelle 2005-2007.

MU-OZ M., SANCHEZ-GONI F., UGARTE F. 1989 - El entomo geo-ambiental del yacimiento arqueologico de Kurtzia. Sopela-Barrika. Costa occidental de Bizkaia. Munibe, 41, p. 107-115. 
NORMAND C. 2002 - L'Aurignacien de la Salle de Saint-Martin (Grotte d'Isturitz; commune de Saint-Martin-d'Aberoue ; Pyrénées-Atlantiques): Données préliminaires sur l'industrie lithique recueillie lors des campagnes 2000-2002. In : F. Bon, J.M. Maíllo-Fernández, D. Ortega (Eds.), Autour des concepts de Protoaurignacien, d'Aurignacien initial et ancien : unité et variabilité des comportements techniques des premiers groupes d'hommes modernes dans le sud de la France et le nord de l'Espagne. Actes de la table-ronde (2003). Espacio, Tiempo y Forma, Serie I. Toulouse, Girona, Madrid : Université de Toulouse le Mirail, p. 145-174 (Prehistoria y Arqueologia, 15).

NORMAND C. 2005 - L'industrie lithique aurignacienne de la salle de Saint-Martin de la grotte d'Isturitz (communes d'Isturitz et de Saint-Martin-d'Arberoue ; Pyrénées-Atlantiques). Toulouse : Université de Toulouse le Mirail, 131 p. DEA.

NORMAND C., TURQ A. 2005 - L'Aurignacien de la Grotte d'Isturitz (France) : la production lamellaire dans la séquence de la salle de Saint-Martin. In : F. Le Brun-Ricalens, J.-G. Bordes, F. Bon (Eds.), Productions lamellaires attribuées à l'Aurignacien : chaînes opératoires et perspectives technoculturelles. Luxembourg, Musée National d'Histoire et d'Art, p. 375-392 (ArchéoLogiques, 1).

NORMAND C., DE BEAUNE, S.A., COSTAMAGNO S., DIOT M.-F., HENRY-GAMBIER D., GOUTAS N., LAROULANDIE V., LENOBLE A., O'FARRELL M., RENDU W., RIOS GARAIZAR J., SCHWAB C., TARRIO VINAGRE A., TEXIER J.-P., WHITE R. 2007 - Nouvelles données sur la séquence aurignacienne de la grotte d'Isturitz (communes d'Isturitz et de Saint-Martin-d'Abreroue: Pyrénées-Atlantiques). In : J. Évin (Ed.), Congrès du centenaire de la Société préhistorique française : Un siècle de construction du discours scientifique en Préhistoire, 26ème Congrès préhistorique de France, Volume 3 « Aux conceptions d'aujourd'hui ». Paris, Société préhistorique française, p. 277-293.

ONORATINI G. 1986 - Découverte en Provence orientale (grotte Rainaude) d'une industrie souche de l'Aurignacien : Cette civilisation est-elle monolithique? Bulletin de la Société Préhistorique Française 83, 8, p. 240-256.

ONORATINI G. 2004 - Le Protoaurignacien : première culture de l'homme moderne de Provence et Ligurie. L'Anthropologie, 108, p. 239-249.

ONORATINI G., SIMON P., SIMONE S. 1999 - Mise en évidence du Protoaurignacien à la Grotte de l'Observatoire (Principauté de Monaco). Bulletin du Musée d'Anthropologie Préhistorique de Monaco, 40, p. 43-56.

PALMA DI CESNOLA A. 1999 - La séquence de la grotte Paglicci (Mont Gargano) dans le cade du leptolithique de l'Italie meridionale. In : D. Sacchi (Ed.), Les faciès leptolithiques du nord-ouest méditerranéen : milieux naturels et culturels. XXIVè Congrès Préhistorique de France, 1994. Carcassonne, Société Préhistorique Française, p. 185-193.

READY E. 2010 - Neandertal foraging adaptations in southwestern France : Implications of Mousterian faunal remains at Gatzarria Cave. Peterborough : Trent University, 229 p. Master's dissertation.

RIEL-SALVATORE J., NEGRINO F. 2009 - Early Upper Paleolithic population dynamics and raw material procurement patterns in Italy. In: M. Camps, C. Szmidt (Eds.), The Mediterranean from 50000 to 25000 BP: turning points and new directions. Oxford, Oxbow Books, p. 211-230.

RIGAUD J.- Ph. 1982 - Le Paléolithique en Périgord : les données du sud-ouest sarladais et leurs implications. Thèse de doctorat es Sciences, Université de Bordeaux 1, 494 p.

SAENZ DE BURUAGA A. 1991 - El Paleolitico superior de la cueva de Gatzarria (Zuberoa, Pais Vasco). Veleia, Vitoria-Gasteiz, Anejos Series Maior, 6, 426 p. 
SAENZ DE BURUAGA A., ÉBRARD D. 2004 - El Musteriense de la cueva de Harregi en Aussurucq, Soule (Excavationes : Pierre Boucher, 1954-1960). Veleia, 21, p. 9-39.

SCHMIDER B. (Ed.) 2002 - L'Aurignacien de la grotte du Renne. Les fouilles d'André Leroi-Gourhan à Arcy-sur-Cure (Yonne). Gallia-Préhistoire, XXXIVº supplément, CNRS, 311 p.

SCHMIDER B., PERPÈRE M. 1997 - Données nouvelles sur l'Aurignacien d'Arcy-sur-Cure (fouilles André Leroi-Gourhan). In : Le Paléolithique supérieur de l'Est de la France : de l'Aurignacien à l'Ahrensbourgien. Actes du colloque de Chaumont, 1994. Reims, Mémoire de la Société Archéologique Champenoise 13, supplément au Bulletin 2, p. 5-13.

SIMONET A. 2009 - Les gravettiens des Pyrénées. Des armes aux sociétés. Toulouse : Université de Toulouse 2 le Mirail, 391 p. Doctoral Thesis.

SIRAKOV N., TSANOVA T., SIRAKOVA S., TANEVA S., KRUMOV I., DIMITROVA I., KOVATCHEVA N. 2007 - Un nouveau faciès lamellaire du debut du Paléolithique supérieur dans les Balkans. Paléo, 19, p. 131-144.

SOLER SUBLIS J., SOLER MASFERRER N., MAROTO J. 2008 - L'Arbreda's archaic Aurignacian dates clarified. Eurasian Prehistory, 5, 2, p. 45-55.

SZMIDT C. 2003 - The Mousterian in Mediterranean France: a regional, integrative and comparative perspective. Oxford : British Archaeological Reports International Series, Volume 1147, 305p.

SZMIDT C. 2009 - From regional patterns to behavioural interpretation : assessing the Middle to Upper Palaeolithic transition in Mediterranean France. In : M. Camps, C. Szmidt (Eds.), The Mediterranean from 50000 to 25000 B.P.: turning points and new directions. Oxford, Oxbow Books, p. 231-254.

SZMIDT C., LAROULANDIE V., DACHARY M., LANGLAIS M., COSTAMAGNO S. 2009a - Harfang, renne et cerf: nouvelles dates $14 \mathrm{C}$ par SMA du Magdalénien supérieur du Bassin aquitain au Morin (Gironde) et Bourrouilla (Pyrénées-Atlantiques). Bulletin de la Société Préhistorique Française, 106,3 , p. 583-587.

SZMIDT C., PÉTILLON J.-M., CATTELAIN P., NORMAND C., SCHWAB C. $2009 \mathrm{~b}$ - Premières dates radiocarbone pour le Magdalénien d'Isturitz (Pyrénées-Atlantiques). Bulletin de la Société Préhistorique Française, 106, 3, p. 588-592.

SZMIDT C.C., BROU L., JACCOTTEY L. 2010a - Direct radiocarbon (AMS) dating of split-based points from the (Proto)Aurignacian of Trou de la Mère Clochette, Northeastern France. Implications for the characterization of the Aurignacian and the timing of technical innovations in Europe. Journal of Archaeological Science, 37, 12, p. 3320-3337.

SZMIDT C.C., MONCEL M.-H., DAUJEARD C. 2010b - New data on the late Mousterian in Mediterranean France : First radiocarbon (AMS) dates at Saint-Marcel Cave (Ardèche). Comptes Rendus Palevol, 9, 4, p. 185-199.

SZMIDT C.C., NORMAND C., BURR G., HODGINS G., LAMOTTA S. 2010C - AMS 14C dating the Protoaurignacian/Early Aurignacian of Isturitz, France. Implications for Neanderthal-modern human interaction and the timing of technical and cultural innovations in Europe. Journal of Archaeological Science, 37, 4, p. 758-768.

TALAMO S., SORESSI M., ROUSSEL M., RICHARDS M., HUBLIN J-J. 2012 - A radiocarbon chronology for the complete Middle to Upper Palaeolithic transitional sequence of Les Cottés (France). Journal of Archaeological Science, 39, p. 175-183.

TARTAR E. 2009 - De l'os à l'outil : caractérisation technique, économique et sociale de l'utilisation de l'os à l'Aurignacien ancien. Etude de trois sites : l'Abri Castanet (secteurs nord et 
sud), Brassempouy (Grotte des Hyènes et Abri Dubalen) et Gatzarria. Paris : Université de Paris I Panthéon-Sorbonne, 2 vol., 373 p. Doctoral thesis.

TEYSSANDIER N. 2006 - Questioning the first Aurignacian : mono or multi cultural phenomenon during the formation of the upper Paleolithic in central Europe and the Balkans. Anthropologie, XLIV/1, p. 9-29.

TEYSSANDIER N. 2008 - Revolution of evolution? The emergence of the Upper Paleolithic in Europe. World Archaeology, 40, p. 493-519.

THIÉBAUT C. (Ed.) 2009 - Des traces et des hommes : Projet de recherche interdisciplinaire sur l'identification des modalités d'acquisition et de traitement des matières végétales et animales au Paléolithique moyen en Europe occidentale. Projet Collectif de Recherche, rapport annuel.

TIXIER J. 1978 - Notice sur les travaux scientifiques. Paris : Université de Paris X Nanterre, 117 p. Doctoral thesis.

TSANOVA T. 2008 - Les débuts du Paléolithique supérieur dans l'Est des Balkans. Réflexion à partir de l'étude taphonomique et techno-économique des ensembles lithiques des sites de Bacho Kiro (couche 11), Temnata (couches VI et 4) et Kozarnika (niveau VII). Oxford : BAR International Series, Volume 1752, $326 \mathrm{p}$.

UTRILLA P., MAZO C. 1996 - Non-flint materials in La Rioja : a tentative interpretation. In : N. Moloney, L. Raposo, M. Santonja (Eds.), Non-flint stone tools and the Palaeolithic occupation of the Iberian peninsula. Oxford, British Archaeological Reports International Series 649, p. 63-80.

UTRILLA P. 2000 - El Paleolitico en el valle Medio des Ebro : Una «revista de prensa» en el cambio de milenio. SPAL 9 : Revista de prehistoria y arqueología de la Universidad de Sevilla, p. 81-108.

VAN KLINKEN G.J. 1999 - Bone collagen quality indicators for palaeodietary and radiocarbon measurements. Journal of Archaeological Science, 26, p. 687-695.

VILLA P. 1982 - Conjoinable pieces and site formation processes. American Antiquity, 47, 2, p. 276-290.

VILLA P., COURTIN J. 1983 - The interpretation of stratified sites : a view from underground. Journal of Archaeological Science, 10, p. 267-281.

WOOD R.E., BRONK RAMSEY C., HIGHAM T.F.G. 2010 - Refining background corrections for radiocarbon dating of bone collagen at ORAU. Radiocarbon, 52, 2-3, p. 600-611.

WOOD R.E., DOUKA K., BOSCATO P., HAESAERTS P., SINITSYN A., HIGHAM T.F.G. 2012 - Testing the ABOX-SC method: Dating known-age charcoals associated with the Campanian Ignimbrite. Quaternary Geochronology, 9, p. 16-26.

ZILHÃO J. 2006 - Neandertals and Moderns mixed, and it matters. Evolutionary Anthropology, 15, p. 183-195.

ZILHÃO J., D’ERRICO F., BORDES J.-G., LENOBLE A., TEXIER J.-P., RIGAUD J.-P. 2008 - Grotte des Fées (Châtelperron) : history of research, stratigraphy, dating, and archaeology of the Châtelperronian type-site. PaleoAnthropology, p. 1-42.

\section{APPENDIXES}




\section{Version abrégée en français}

Datations radiocarbone (par SMA) de l'Aurignacien ancien, du Protoaurignacien et du Moustérien à hachereaux de la Grotte de Gatzarria, Pyrénées-Atlantiques, France.

\section{Introduction}

Située en zone pyrénéenne française, la Grotte de Gatzarria (fig. 1) représente un site majeur pour aborder les débats sur la transition Paléolithique moyen-Paléolithique supérieur étant donné que cette cavité comprend une séquence stratifiée de Moustérien (avec Moustérien à hachereaux), Châtelperronien, ainsi que des niveaux aurignaciens (Protoaurignacien, Aurignacien ancien et Aurignacien évolué).

Dans cet article sont présentées les datations par radiocarbone (spectrométrie de masse par accélérateur et avec ultrafiltration) entreprises sur les collections de ce site qui sont conservées au Musée National de Préhistoire des Eyzies (France), grotte fouillée il y a quarante ans par G. Laplace. Ces datations sont les premières à avoir été obtenues sur les collections de Gatzarria et se rattachent à un projet plus large de datations sur la période dite de 'transition' Paléolithique moyen-Paléolithique supérieur, dirigé par l'une d'entre nous (C.C.B-S). Nous discutons tout particulièrement dans cet article du protocole de sélection des échantillons. Ceci comprend une évaluation de l'intégrité stratigraphique du site (utilisant surtout la méthode des projections verticales et une étude non systématique de raccords et de remontages), la détermination des meilleurs carrés à échantillonner, ainsi qu'une évaluation des ossements pour choisir ceux qui ont le plus de chance d'être associés à l'occupation humaine (os d'ongulés, striés si possible). Nous insistons sur l'importance de la mise en place d'un tel protocole dans les études visant à dater des collections issues de fouilles anciennes.

L'objet de cet article est de présenter les datations exclusives de Gatzarria. Les révisions techno-économiques des industries du Moustérien à hachereaux et du Protoaurignacien de ce site seront présentées de manière exhaustive dans des publications ultérieures. Cependant, afin d'expliquer les choix effectués quant aux échantillons à dater, nous présenterons ici de manière succincte les industries qui nous intéressent dans leur contexte stratigraphique, ainsi que la méthode de fouille de ce gisement.

Les points discutés dans cet article sont les suivants:

(1) l'âge du Moustérien à hachereaux de Gatzarria (est-ce un Moustérien tardif ou plus ancien ?) ; (2) les âges du Protoaurignacien et de l'Aurignacien ancien de Gatzarria comparés aux sites proches, de France, Italie et Espagne; (3) La question d'une éventuelle perduration tardive du Protoaurignacien dans certaines régions et ses liens avec l'Aurignacien ancien.

L'organisation de l'article est la suivante: introduction (section 2) sur l'historique du site et les séries, ainsi que les méthodes de fouille employées par G. Laplace; présentation ensuite des analyses réalisées pour établir les zones les plus appropriées pour l'échantillonnage (section 3) et la méthodologie de datation (section 4). L'article se termine en replaçant ces nouveaux résultats (section 5) dans un plus large contexte (section 6), notamment technologique et chronologique, en discutant l'incidence éventuelle sur les comportements humains de cette période. 


\section{Historique du site et méthodologie de fouille}

Étudiée en grande partie par G. Laplace entre 1961 et 1976, cette petite cavité de $13 \mathrm{~m}$ de long, par $4 \mathrm{~m}$ de large, par $2 \mathrm{~m}$ de hauteur, a été fouillée par décapages horizontaux de $10 \mathrm{~cm}$ (= 'Taille') ou $5 \mathrm{~cm}$ (= 'demi-taille'), suivant les couches sédimentaires. Le sol dans la première partie de la grotte est sub-horizontal, puis continu vers le fond en s'inclinant rapidement (fig. 2 et voir conséquences ci-dessous). Les pièces ont été repérées dans un espace orthonormé tridimensionnel (Laplace 1971; Laplace et Méroc 1954) permettant de les replacer dans le niveau d'occupation auquel elles appartiennent (fig. 2, 3). La fraction fine et/ou brute du lithique et la majorité de la faune, par contre, n'ont été référencées dans le meilleur des cas que par rapport à la couche, au carré auquel elles appartiennent, parfois au sous-carré, et au numéro de décapage.

\section{Stratigraphie du remplissage et ensembles archéologiques}

La puissance du remplissage fouillé ne dépasse jamais $2 \mathrm{~m}$ (fig. 3 et tabl. 1) et comprend, entre autres, les niveaux archéologiques Cjr (Moustérien à hachereaux), Cjn2 (Protoaurignacien) et Cbf (Aurignacien ancien), que nous avons datés. Les industries lithiques et osseuses ont été étudiées principalement par G. Laplace et A. Saenz de Buruaga (Laplace 1966a, b; Laplace et Saenz de Buruaga 2002; Laplace et al. eds. 2006; Lavaud 1980; Lévêque 1966; Saenz de Buruaga 1991; Simonet 2009; Tartar 2009) (note 3). Depuis peu, ces ensembles font l'objet de nouvelles études, dans le cadre d'un mémoire de maitrise (Ready 2010), ainsi que de thèses de doctorat, et notamment par deux d'entre nous pour les industries lithiques du Moustérien à hachereaux (M.D.) et du Protoaurignacien (L.E.).

La couche Cjr représente un Moustérien à hachereaux. L'échantillon étudié concerne 1552 vestiges lithiques. L'exploitation du quartzite a été largement privilégiée (89\%). La chaine opératoire de production d'éclats est majoritairement discoïde unifacial et secondairement bifacial (fig. 4). L'objectif principal du débitage consiste en l'obtention d'éclats à tranchant périphérique. Six hachereaux en ophite sont aussi associés à cette industrie (fig. 5). L'outillage sur éclat associé à ce débitage est majoritairement composé de racloirs, suivis par les encoches et denticulés (fig. 6). Nommé 'Vasconien' par F. Bordes (1953), cette industrie a été définie comme faciès régional du Pays basque, caractérisé par la présence de hachereaux. Si certains perçoivent cette industrie comme étant simplement un variante fonctionnelle du Moustérien plutôt qu'un faciès particulier (Cabrera Valdés 1983; Freeman 1966, 1969-70), de récentes études ont cependant montré que les ensembles vasconiens partagent aussi des aspects technologiques qui les unifient (Deschamps 2008, 2009).

L'ensemble de la Cjn2 (fig. 7 et 8; tabl. 2 et 3) s'inscrit parfaitement dans la définition du Protoaurignacien. Cette industrie est tournée vers l'obtention exclusive de lames peu robustes et de lamelles élancées, étroites et de profil rectiligne, produites au cours d'une même chaîne opératoire. Parmi les lames et les lamelles retouchées, les lamelles Dufour sous-type Dufour sont le type le plus représenté (fig. 7).

L'ensemble lithique Aurignacien ancien Cbci-cbf n'a pas fait l'objet d'une étude récente. Les données publiées permettent cependant d'attribuer de manière probante ce niveau à la phase ancienne de l'Aurignacien (Laplace 1966a,b; Saenz de Buruaga 1991; Normand 2005). 


\section{Évaluation de la stratigraphie de G. Laplace à Gatzarria}

Si l'on observe un profil du remplissage (fig. 2), on peut penser que les dépôts ont suivi la topographie de la grotte et que, sub-horizontaux dans la première partie de la grotte, ils auraient tendance à s'incliner vers le fond. On pouvait donc s'attendre à ce que les couches soient beaucoup plus mélangées en aval. Nos observations du matériel pour la Cjn2 et la Cjr ont confirmé cette hypothèse. Il s'avère en effet que la partie avale présente un matériel beaucoup moins homogène qu'en amont. Cela est vrai tant du point de vue des types de pièces que de la représentativité des matières premières ou encore des états de surface des pièces.

G. Laplace (1962) précise qu'« Il n'existe pas de niveau stérile entre les différentes couches archéologiques [de la couche sédimentologique CJ], toutes cependant nettement individualisées sans indice ou possibilité apparente de contamination réciproque ». Or, même s'il a pris soin de repérer les changements sédimentaires au cours de la fouille, nous avons compris qu'il fouillait de manière horizontale. De plus, notons que 4 des couches -Moustérien supérieur (Cj), Châtelperronien (Cjn3) et Protoaurignacien (Cjn2 et Cjn1) (fig. 7 et 8; tabl. 2-5) - sont contenues dans un même niveau sédimentaire, et étaient superposées sans niveau stérile pour les séparer (Laplace 1966b). Dès lors, « [la couche jaune a été divisée] en horizons ou niveaux industriels repérables, à ce jour, par la seule méthode des coordonnées cartésiennes » (Laplace 1963). On peut donc s'attendre à ce que les couches se recoupent au moins en partie.

Nous avons donc utilisé la méthode des projections verticales des artéfacts pour « corriger ou confirmer, dans la séquence stratigraphique, les limites des niveaux archéologiques telles qu'elles ont été établies lors des fouilles » (traduit de Villa 1982 p. 277). Il s'avère qu'effectivement les couches sont au contact les unes des autres et qu'elles se recouvrent en partie.

Cependant, les analyses menées par deux d'entre nous sur la Cjn2 et la Cjr montrent que pour la partie sub-horizontale de la grotte, ces ensembles sont cohérents d'un point de vue techno-typologique. L'état de surface des pièces présente un degré identique d'altération, venant ainsi confirmer l'homogénéité globale de ces niveaux. Ces analyses nous ont conduit à ne prendre en compte que la partie antérieure de la grotte pour les analyses techno-typologiques comme pour l'échantillonnage à dater. Selon nous, la cohérence techno-typo-taphonomique des ensembles échantillonnés est un argument fort pour attester leur intégrité, et donc permettre d'entreprendre ce programme de datation.

Gatzarria comprend aussi un niveau attribué au Châtelperronien par Laplace (Cjn3). Les collections de ce niveau, étudiées par d'autres chercheurs, n'ont pas été réévaluées par nous et nous ne l'avons donc pas daté. Cependant, d'après nos observations sur ce site, au vu de la fine épaisseur du niveau, du fait qu'il ne se distingue pas d'un point de vue sédimentaire des niveaux sus- et sous-jacents et étant donné les processus postdépositionnels évoqués, il y de fortes chances à ce qu'il contienne des éléments des niveaux sous- et sus-jacents. Ce mélange poserait problème pour les datations d'ossements. Cette hypothèse reste à vérifier sur la collection elle-même.

Choix de la zone et des échantillons à dater 
Pour les carrés particulers à échantillonner, nos analyses, ainsi que notre étude non systématique de quelques raccords et remontages dans le Protoaurignacien (fig. 9) nous a montré que les carrés les plus fiables étaient ceux de $3 \mathrm{E}, 3 \mathrm{~F}$ (préférables), ainsi que ceux de 2E, 2F. Ces carrés ont une stratigraphie bien dilatée, un grand nombre d'objets, des objets bien repérés/marqués et ne présentent pas d'inclinaison ni de déplacements verticaux significatifs. Le choix des échantillons a été fait de manière à bien assurer le lien entre objet daté et occupation humaine. Le choix s'est donc porté vers les os d'ongulés, de préférence striés, ayant un bon état de surface et repérés en 3D (ou au moins au décapage). Des échantillons ont été pris de trois niveaux : Cjr, Cjn2 et Cbf (tabl. 6). Pour Cjn2, nous avons choisi des échantillons au centre du niveau pour éviter la zone de contact avec les niveaux sus-et sous-jacents.

\section{Résultats}

Toutes les étapes de datation ont été faites au Oxford Radiocarbon Accelerator Unit (ORAU), ce qui inclut une étape d'ultrafiltration (Brock et al. 2007, 2010; Bronk-Ramsey et al. 2002, 2004a,b; Brown et al. 1988; Higham et al. 2006; Wood et al. 2010). Les taux de collagène, ainsi que les mesures isotopiques et élémentaires des échantillons sont dans les marges normales (tabl. 7) (Burleigh et al. 1984; DeNiro 1985; Hedges et van Klinken 1992; van Klinken 1999). Les datations sont cohérentes avec la stratigraphie, même s'il faut tenir compte d'un recouvrement chronologique entre certaines d'entre elles.

Pour résumer donc notre approche, nous avons entrepris plusieurs analyses avant d'opérer un choix d'échantillons. Pour commencer, nous avons fait des analyses techno-typologique, de matières premières et de l'état de surface des collections de Cjn2 et de Cjr. Celles-ci nous ont montré l'homogénéité de la zone antérieure de la grotte, mais pas de la zone postérieure; nous avons donc visé l'avant de la grotte. Deuxièmement, pour cette zone, nous avons projeté les pièces ayant été coordonnées en 3D. Ceci confirma le fait que les couches se recouvraient partiellement dans l'unité sédimentologique CJ. Ceci nous permetta aussi de déterminer les limites des couches afin que nous puissions éviter de prendre des échantillons près de leurs surfaces de contact. Finalement, notre étude non systématique des raccords et des remontages en Cjn2, dans la zone considérée, nous a confirmé qu'il n'y avait pas de déplacements verticaux significatifs. Ensuite, parmi ces contraintes de zone et de profondeur, nous avons visé des échantillons épais, en bonne condition, déterminables et, si possible, ayant des stries. De plus, nous nous sommes assurés qu'au laboratoire ces échantillons seraient sujets à de bonnes techniques de prétraitement.

\section{Discussion}

Aperçu des problématiques de cette période/région

Dans les rares sites où l'on trouve en stratigraphie le Protoaurignacien et l'Aurignacien ancien, le Protoaurignacien est toujours sous-jacent à l'Aurignacien ancien (Arrizabalaga et al. 2009; Bazile et Sicard 1999; Bordes 2006; Bordes et al. 2008; Eizenberg 2006; Kuhn et Stiner 1998; Laplace 1966b; Laplace et al. eds. 2006; Le Brun-Ricalens et Bordes 2007; Lhomme 1976; Normand et al. 2007; Onoratini 2004; Onoratini et al. 1999; Szmidt et al. 2010c; Talamo et al. 2012). Ceci a ainsi conduit la plupart des chercheurs à ne discuter que de la stricte ancienneté du premier par rapport au second (note 4). Jusqu'à récemment, chacun de ces deux faciès semblait également avoir une répartition géographique différente, le Protoaurignacien plutôt situé en région méditerranéenne/ 
pyrénéenne et l'Aurignacien ancien dans les zones Atlantique/Europe centrale. De plus, d'après de récentes études technologiques, la production de lames et de lamelles est gérée de manières différentes dans chacun des deux faciès (Arrizabalaga et al. 2009; Bazile et Sicard 1999; Bon 2002, 2006a, b; Bon et al. eds. 2006; Bordes et al. 2008; Chazan 2001; Conard et Bolus 2006; Le Brun-Ricalens 1993, 2005; Le Brun-Ricalens et Bordes 2007; Mellars 2006; Normand 2002; Teyssandier 2008). Ils diffèrent aussi typologiquement, ainsi que dans leurs éléments de parure et d'outils osseux. Les datations plaçaient le Protoaurignacien entre 38 ka et 34,7 ka14C BP, et l'Aurignacien ancien entre 35 et 32 ka14C BP (Jöris et Street 2008).

Certains travaux récents montrent que la séparation chronologique, phylétique et/ou géographique envisagée de ces faciès aurignaciens n'est par forcément valable. La possibilité d'une contemporanéité, même partielle, entre les deux (du moins sur un plan macro-régional), d'un possible lien phylétique entre eux (développement de l'un à partir de l'autre; pointes à base fendue dans les deux), ainsi que d'aires géographiques bien plus recouvrantes, sont envisageables et ce même si, comme nous l'avons évoqué, ces deux techno-complexes n'ont jusqu'à présent jamais été trouvés interstratifiés (Arrizabalaga et al. 2009; Bordes et al. 2008; Brou 1997; Le Brun-Ricalens et Bordes 2007; Liolios 2006; Normand et al. 2007; Sirakov et al. 2007; Soler Subils et al. 2008; Szmidt et al. 2010a,c; Teyssandier 2008).

En ce qui concerne le Moustérien à hachereaux, il est possible qu'il date de la fin du Moustérien, comme le suggèrent les dates de < 45000 BP sur d'autres sites (Allard 1993 ; Cabrera et al. 1996 ; Deschamps 2008; Maillo Fernandez et al. 2004; Mourre et al. 2005, 2006 ; Muñoz et al. 1989 ; Saenz de Buruaga et Ébrard 2004 ; Utrilla 2000). Il est donc envisageable qu'il recouvre au moins en partie l'Aurignacien et qu'il représente le comportement de certains derniers Néandertaliens.

À l'issue de nos investigations, en ce qui concerne les relations phylétiques et chronologiques entre le Protoaurignacien et l'Aurignacien ancien et la position chronologique du Moustérien à hachereaux (Vasconien), il est à relever les aspects suivants:

1. D'un point de vue méthodologique, il est clair que choisir des échantillons aléatoirement d'après l'attribution des couches de Laplace aurait, selon le carré choisi, produit des datations erronées. Nous encourageons donc l'évaluation de l'intégrité stratigraphique et des attributions d'objets d'un site avant de faire des datations sur collections de fouilles anciennes. Nous sommes aussi en faveur de l'application d'un protocole strict dans le choix, le nettoyage et l'évaluation des échantillons de sites pour datations, comme nous l'avons fait ici et pour d'autres sites (Langlais et al. 2010; Szmidt et al. 2009 a,b, 2010 a,b,c). Ceci pour établir le meilleur lien possible entre les objets datés et les problèmes à resoudre concernant l'occupation humaine d'un site.

2. Les échantillons du Moustérien à hachereaux de Gatzarria sont plus vieux que les limites mesurables par datations radiocarbone ( $>47400$ et > Fi 50300 14C BP). Les incertitudes concernant la chronologie du Vasconien sont liées à deux types d'informations qui proposent des conclusions différentes. D'une part, les résultats des datations par le radiocarbone donnent des dates aux alentours de $40000 \mathrm{BP}$ pour l'ensemble des sites. D'autre part, le spectre faunique identifié sur plusieurs sites vasconiens semble caractéristique d'un climat tempéré qui serait, d'après certains auteurs (Jaubert 2007), plutôt contemporains de la fin du MIS 5. Les datations de Cjr 
montrent que le Moustérien à hachereaux de Gatzarria n'est pas un Moustérien final recouvrant une partie de l'Aurignacien. Ces dates sont cohérentes avec la position de cette couche séparée de l'Aurignacien par un niveau moustérien et un niveau châtelperronien. Par contre, ceci n'empêche par d'autres sites vasconiens d'être récents. Ces résultats ne permettent ni de confirmer, ni de refuter l'hypothèse d'un Vasconien datant du MIS 5. Cependant il serait nécessaire de tester d'autres types de datations absolues afin de préciser la chronologie de ce Moustérien.

3. Dans le Protoaurignacien (Cjn2), l'échantillon se trouvant plus profondément en stratigraphie (cjn2 3E 78.25.70) a une date plus ancienne que celui se trouvant plus haut (cjn2 3E 69.99.95). Le résultat de ce premier (36 $300 \pm 700$ 14C BP) est en accord (recouvrement à 1 ou 2 écarts-types) avec beaucoup de dates de sites du Protoaurignacien de la région pyrénéenne (France et Espagne) (Arrizabalaga et al. 2009; Soler Subils et al. 2008; Szmidt et al. 2010c (note 5). Il est également statistiquement équivalent ou plus ancien ( $>2$ écarts-types) que les dates du Protoaurignacien de sites en Italie et en France méditerranéenne (Bazile et Sicard 1999; Douka et al. 2012; Higham et al. 2009; Riel-Salvatore et Negrino 2009; Wood et al. 2012). Ce résultat tend à confirmer une apparition relativement précoce du Protoaurignacien dans la zone atlantique en comparaison d'autres régions, même s'il faut rester prudent sur l'équivalence techno-typologique de ces diverses régions et séries et que les datations de certains sites doivent être ré-évalués.

4. Les résultats confirment aussi le développement également précoce de l'Aurignacien ancien, peut-être au-delà de $34000 \mathrm{BP}$, grâce aux deux estimations concordantes obtenues pour le niveau Cbf ( $34250 \pm 550$ et $34400 \pm 550$ 14C BP). Elles sont antérieures à beaucoup de dates de l'Aurignacien ancien, mais équivalentes aux plus anciennes d'entre elles dans certaines régions avoisinantes (Arrizabalaga et al. 2009; Jöris et Street 2008; Mellars 2000; Zilhão et al. 2008). Ces dates de Cbf sont aussi anciennes, voire plus anciennes, que certaines de celles obtenues pour le Protoaurignacien dans le sud-est de la France et l'Italie (Bazile et Sicard 1999; Riel-Salvatore et Negrino 2009).

Par contre, il faut noter que les grands écarts-types de la majorité des datations aurignaciennes (sensu lato), ainsi que le manque de renseignements concernant la prise d'échantillons, l'intégrité de la stratigraphie, la qualité de leur nettoyage et les valeurs chimiques des échantillons, rend difficile leur interprétation.

5. Gatzarria peut aussi contribuer aux discussions concernant la perduration du Protoaurignacien. En effet, l'échantillon plus haut de Cjn2 (33 $800 \pm 550$ 14C BP) recouvre certaines dates récemment obtenues (avec ultrafiltration) d'ensembles protoaurignaciens (Szmidt et al. 2010a; Talamo et al. 2012). Jusqu'à récemment les dates 'jeunes' du Protoaurignacien pouvaient être dûes à un nettoyage incomplet (contaminations). Ces récentes datations avec ultrafiltration devraient être plus fiables. Il est donc possible que le Protoaurignacien ait perduré plus récemment qu'envisagé, c'est à dire recouvrant le début de la période de l'Aurignacien ancien, du moins sur un plan macro-régional de l'Europe de l'ouest (note 6) - la transition (ou remplacement) de l'un vers (par) l'autre pouvant se produire entre 34900 et 33300 (à deux écarts-types) à Gatzarria (fig. 10). 


\section{NOTES}

1. In fact, although Laplace (1966 a, b) defined the Protoaurignacian largely based on Pyrenean sites such as Gatzarria and Les Abeilles, he integrated sites from a much wider region of Europe soon after. More recently, this facies was identified and confined largely to the southern European regions. It is only in the last decade that the Proto-Aurignacian has, once again, been viewed as a larger geographical phenomenon (for more elaborate discussion of the history of research on the Proto-Aurignacian, see Bon 2006b). It is important to note, though, that most researchers today view the Proto-Aurignacian in a different way than did G. Laplace, both in terms of definition and the process of its emergence. To distinguish these in English, the spelling 'Protoaurignacian' is used strictly in the Laplace sense here, whereas 'Proto-Aurignacian' is used to denote the current definition of this industry. For overall background on the industries and issues of this period, see Section 6 of the present article. In the French text, 'Protoaurignacien' is used in the current (non-Laplace) meaning of the term. The only exception to this is Table 1, where it refers to Laplace's nomenclature.

2. Some researchers acknowledge, however, that the Proto-Aurignacian may have persisted in some regions of Europe, such as in Italy. If so, this 'recent' Proto-Aurignacian would be contemporaneous with the Classic Aurignacian of the Atlantic region, for instance (Bon 2002).

3. In this region, one of the very few sites to have produced much younger dates, ones which have been questioned, in fact, is Labeko Koba (layer VII) (31 $455 \pm 915{ }^{14} \mathrm{C}$ BP and $26910 \pm 530{ }^{14} \mathrm{C}$ BP) (Arrizabalaga et al. 2003, 2009).

4. We should note that the upper Cjn2 date (Proto-Aurignacian) and the dates of layer Cbf (Classic Aurignacian) cannot be distinguished statistically (their one standard deviation ranges overlap), even if they may appear out of order if one, incorrectly, does not consider their standard deviations. Of course, statistical equivalence does not necessarily mean that they existed at the site during exactly the same years.

\section{ABSTRACTS}

The site of Gatzarria (Pyrenean France) was excavated in the 1960s and 1970s by Georges Laplace. The importance of the site lies in the fact that it contains a stratified sequence of Aurignacian industries (Proto-Aurignacian - Classic Aurignacian - Late Aurignacian), a Châtelperronian layer, as well as a long sequence of Mousterian layers (including what has been termed the Vasconian Mousterian). It is thus a key site for assessing the Middle to Upper Palaeolithic transition as well as the techno-typological and chronological relationship between Aurignacian industries.

As such, we decided to date animal bone samples by accelerator mass spectrometry (AMS) radiocarbon method (with ultrafiltration) from the Classic Aurignacian (Cbf), Proto-Aurignacian (Cjn2) and Vasconian Mousterian (Cjr) layers. After detailed evaluation of the stratigraphy of the site based on lithic analyses, projections, as well as refits of the Laplace excavation collection, we determined the most appropriate squares from which to sample and bones to select. The results are stratigraphically coherent, with an overlap in chronometric dates between the two early stratified Aurignacian industries : Classic Aurignacian $34250 \pm 550$ and $34400 \pm 550$ 14C BP; ProtoAurignacian : $36300 \pm 700$ and $33800 \pm 55014 \mathrm{C}$ BP. The Vasconian Mousterian, which has been argued as a late Mousterian facies by radiometric data, is older at this site than has been argued 
at other sites: Vasconian Mousterian: > 47400 and > 50300 14C BP. These represent the first dates ever obtained on this key site.

This article presents the site, the selection and dating methodology and discusses the results within the larger western European Middle to Upper Palaeolithic transition context, particularly that of the Pyrenean region. The critical importance of stratigraphy integrity assessments of museum collections of sites excavated before the benefit of geoarchaeological analyses is emphasized here, especially when considering chronometric dating.

\section{INDEX}

Keywords: Radiocarbon dating, Proto-Aurignacian, Classic Aurignacian, Vasconian Mousterian, re-assessment of old excavations

Mots-clés: Datations radiocarbone, Protoaurignacien, Aurignacien ancien, Moustérien à hachereaux, ré-évaluation de fouilles anciennes

\section{AUTHORS}

\section{CAROLYN C. BARSHAY-SZMIDT}

University of Pennsylvania Museum of Archaeology and Anthropology, 3260 South Street, Philadelphia, PA 19104-6324 USA and Archaeology Centre, University of Toronto, 19 Russell Street, Toronto, ON M5S 2S2 Canada - c.szmidt@utoronto.ca

\section{LAURA EIZENBERG}

University of Toulouse Le Mirail, UMR 5608 - TRACES, 5, allées Antonio Machado, 31058 Toulouse - cedex 9, France - laura.eizenberg@univ-tlse2.fr - deschamp@univ-tlse2.fr

\section{MARIANNE DESCHAMPS}

University of Toulouse Le Mirail, UMR 5608 - TRACES, 5, allées Antonio Machado, 31058 Toulouse - cedex 9, France - laura.eizenberg@univ-tlse2.fr - deschamp@univ-tlse2.fr 